\title{
Recombinant Bovine Growth Hormone-Induced Metabolic Remodelling Enhances Growth of Gilthead Sea-Bream (Sparus aurata): Insights from Stable Isotopes Composition and Proteomics
}

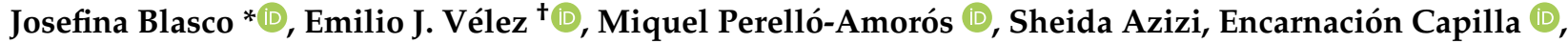 \\ Jaume Fernández-Borràs and Joaquim Gutiérrez
}

Citation: Blasco, J.; Vélez, E.J.; Perelló-Amorós, M.; Azizi, S.; Capilla, E.; Fernández-Borràs, J.; Gutiérrez, J.

Recombinant Bovine Growth

Hormone-Induced Metabolic Remodelling Enhances Growth of Gilthead Sea-Bream (Sparus aurata): Insights from Stable Isotopes Composition and Proteomics. Int. J. Mol. Sci. 2021, 22, 13107. https:// doi.org/10.3390/ijms222313107

Academic Editor: Berta Levavi-Sivan

Received: 12 November 2021

Accepted: 1 December 2021

Published: 3 December 2021

Publisher's Note: MDPI stays neutral with regard to jurisdictional claims in published maps and institutional affiliations.

Copyright: (c) 2021 by the authors. Licensee MDPI, Basel, Switzerland. This article is an open access article distributed under the terms and conditions of the Creative Commons Attribution (CC BY) license (https:// creativecommons.org/licenses/by/ $4.0 /)$.
Department of Cell Biology, Physiology and Immunology, Faculty of Biology, University of Barcelona, 08028 Barcelona, Spain; emilio-jose.velez-velazquez@inrae.fr (E.J.V.); miquelperelloamoros@gmail.com (M.P.-A.); sheidaazizi@ub.edu (S.A.); ecapilla@ub.edu (E.C.); jaume.fernandez@ub.edu (J.F.-B.); jgutierrez@ub.edu (J.G.)

* Correspondence: jblasco@ub.edu; Tel.: +34-934-021-526

+ Current address: Université de Pau et des Pays de l'Adour, E2S UPPA, INRAE, UMR1419 Nutrition Métabolisme et Aquaculture, F-64310 Saint-Pée-sur-Nivelle, France.

Abstract: Growth hormone and insulin-like growth factors (GH/IGF axis) regulate somatic growth in mammals and fish, although their action on metabolism is not fully understood in the latter. An intraperitoneal injection of extended-release recombinant bovine growth hormone (rbGH, Posilac ${ }^{\circledR}$ ) was used in gilthead sea bream fingerlings and juveniles to analyse the metabolic response of liver and red and white muscles by enzymatic, isotopic and proteomic analyses. GH-induced lipolysis and glycogenolysis were reflected in liver composition, and metabolic and redox enzymes reported higher lipid use and lower protein oxidation. In white and red muscle reserves, $\mathrm{rBGH}$ increased glycogen while reducing lipid. The isotopic analysis of muscles showed a decrease in the recycling of proteins and a greater recycling of lipids and glycogen in the rBGH groups, which favoured a protein sparing effect. The protein synthesis capacity (RNA/protein) of white muscle increased, while cytochrome-c-oxidase (COX) protein expression decreased in $\mathrm{rBGH}$ group. Proteomic analysis of white muscle revealed only downregulation of 8 proteins, related to carbohydrate metabolic processes. The global results corroborated that GH acted by saving dietary proteins for muscle growth mainly by promoting the use of lipids as energy in the muscles of the gilthead sea bream. There was a fuel switch from carbohydrates to lipids with compensatory changes in antioxidant pathways that overall resulted in enhanced somatic growth.

Keywords: metabolism; cytochrome-c-oxidase; citrate synthase; redox enzymes; $\delta^{13} \mathrm{C} / \delta^{15} \mathrm{~N}$; white muscle proteome

\section{Introduction}

The possibility of obtaining fish of greater size and quality in shorter times, inducing their growth from the first stages of their life, represents a challenge in the improvement of aquaculture. Growth hormone $(\mathrm{GH})$ is the main endocrine inducer of fish growth; therefore, its manipulation under controlled rearing conditions can be considered as a rapid approach to explore the maximum inherent growth capacity of a given species that could potentially be recruited for aquaculture purposes, through long-term domestication and selective breeding programs [1]. One of the most important aspects in the knowledge of GH in fish was the development of a GH transgenic salmon [2]. These authors demonstrated, by using recombinant bovine $\mathrm{GH}$ ( $\mathrm{rBGH}$, Posilac $($ )), that the transgenesis resulted in a certain level of saturation for growth, as rBGH administration had a lower effect enhancing growth in transgenic animals compared to their corresponding control group. 
The GH/insulin-like growth factor (IGF) system (GH/IGF) is the main regulator of somatic growth in vertebrates, and it has been extensively studied, also in fish [3-12]. Thus, the number of receptors for both hormones in different tissues and the activation of signalling pathways through them have been investigated in different species [13,14], including gilthead sea bream [10-12]. GH administration increases growth rates in fish [8]. Moreover, GH is a pleiotropic hormone involved in several vital processes in vertebrates, such as nutrition, metabolism, reproduction, physical activity, neuroprotection, immunity, osmoregulation and even social behaviour [15]. The biological actions of GH as a major growth and metabolic modulator have been utilized in different applied fields including aquaculture $[2,11,12]$. All these reinforce the multidisciplinary interest on GH and the need for progressing in its knowledge across vertebrates.

The metabolic function of GH/IGF axis is noticeable as it can regulate the three major metabolites (sugars, lipids and proteins) and thus significantly increase the animal growth rate, promote the growth of muscles and bones and decrease the fat content $[16,17]$. As in mammals [18], GH has a dual role in fish, since it exerts a lipolytic effect on target tissues such as liver and adipose tissue in vivo $[12,19,20]$ and in vitro [12,21,22], and at the same time, it has a hyperglycaemic effect by mobilizing liver glycogen [23-26]. GH and IGF-I treatments, both singly and in combination, significantly increased the glycogen content of hepatocytes isolated from fed Artic char [27]. Thereby, in vivo GH administration suppressed the potential for glycolysis but stimulated gluconeogenic and glycogenolytic pathways. The mobilization of energy substrates, lipids and glycogen enables protein savings leading to greater growth. Thus, white muscle protein accretion has been observed in rainbow trout after $\mathrm{GH}$ injection [28,29], and the anabolic effects of $\mathrm{GH}$ on protein turnover have been reflected as increased oxygen consumption [30]. However, most of the GH effects in carbohydrate metabolism have been analysed on the liver tissue, and information on the GH-induced consequences in muscle is scarce. Therefore, a holistic view using proteomics could provide valuable information on the metabolic pathways that may have been modified after an exogenous GH treatment. This tool has made possible to demonstrate that a similar rapid growth phenotype can be achieved via selective breeding or by GH transgenic fish, although the proteomic profile between the two revealed differences in the metabolic pathways involved [31].

Stable isotope analysis $\left({ }^{13} \mathrm{C}\right.$ and $\left.{ }^{15} \mathrm{~N}\right)$ in representative growth tissues, such as muscle, can offer valuable information about reserves turnover [32], because enzymes involved in catabolic processes, such as decarboxylation and deamination, show a preference for light isotopes [33], causing tissues to become enriched with heavier isotopes (e.g., ${ }^{13} \mathrm{C}$ and $\left.{ }^{15} \mathrm{~N}\right)$. This factor of discrimination is known as fractionation. Nitrogen fractionation $\left(\Delta^{15} \mathrm{~N}\right)$ is a good marker of protein balance, because it reflects protein turnover and retention efficiency [32,34]. In previous studies, we have evaluated the use of stable isotopes as indicators of feeding balance for assessing the optimal nutritional conditions of growing fish [34-37]. In the case of gilthead sea bream, we have observed an inverse relationship between dietary protein content and muscle nitrogen fractionation and that this fractionation is also inversely related to the specific growth rate (SGR) [37]. Therefore, we hypothesized that the set of modifications and metabolic changes induced by GH administration should be reflected in the isotopic composition of the fish tissues.

In the present study, we analysed the effects of $\mathrm{rBGH}$ treatment in both fingerlings and juveniles of gilthead sea bream, focusing the attention to the metabolic responses of liver and muscle tissues. Using a variety of techniques, we aimed to provide a valuable knowledge of the adaptation of those tissues to maintain/prolong GH administration. Specifically, the recycling of the reserves was studied in depth by interpreting the isotopic composition changes, in addition to the proximal composition and the key enzymes activity of the intermediate and energy metabolism, as well as the redox balance. From a holistic perspective, the differences that occur in the muscle proteome are shown together with analysis of the global effects on specific metabolic pathways. This work complements our previous studies on the effects of rBGH on myogenic and lipolytic factors and the GH/IGF 
axis in gilthead sea bream [11,12]. Although previous research in fish shows that $\mathrm{rBGH}$ is a good inductor of growth, the current legislations and the consumers' criteria are not in line with the idea of using rBGH in fish. The purpose of this study was never to apply this to fish, but to know their potential to grow to later on find approaches or natural conditions where the secretion of GH and/or IGF-I is enhanced.

\section{Results}

\subsection{Growth Performance, Proximal and Isotopic Composition}

The effects of rBGH injection on somatic growth parameters and feed conversion rate on gilthead sea bream fingerlings and juveniles are shown in Table 1 . The final body weight was significantly increased in both age groups injected with $\mathrm{rBGH}(p<0.05$, $p<0.01$, respectively) compared to their corresponding control fish, which resulted in a significant increase of SGR in both groups as well $(p<0.05, p<0.001)$. The condition factor (CF) was modified neither in fingerlings nor in juveniles. The hepatosomatic index (HSI) was significantly reduced in both experimental groups $(p<0.01)$, but no differences were observed in mesenteric fat index (MFI) of rBGH-injected groups compared to their corresponding control groups. The musculosmatic index (MSI) obtained in juveniles did not show significant differences. The food conversion ratio (FCR) decreased in all $\mathrm{rBGH}$-injected fish compared to control groups, but it was significant only in the case of juveniles.

Table 1. Somatic growth parameters and feed conversion rate (FCR) after 6 and 9 weeks of rBGH injection on gilthead sea bream fingerlings and juveniles.

\begin{tabular}{|c|c|c|c|c|c|c|}
\hline & \multicolumn{2}{|c|}{ Fingerlings } & \multicolumn{4}{|c|}{ Juveniles } \\
\hline & Control & $\mathrm{rbGH}$ & & Control & rbGH & \\
\hline Initial B.W. & $1.04 \pm 0.02$ & $1.01 \pm 0.05$ & & $16.3 \pm 0.06$ & $16.3 \pm 0.34$ & \\
\hline Final B.W. & $8.07 \pm 0.25$ & $8.84 \pm 0.18$ & $*$ & $57.2 \pm 1.49$ & $70.6 \pm 2.20$ & $* *$ \\
\hline SGR & $4.9 \pm 0.08$ & $5.2 \pm 0.07$ & * & $1.98 \pm 0.02$ & $2.33 \pm 0.02$ & $* * *$ \\
\hline CF & $1.5 \pm 0.01$ & $1.5 \pm 0.01$ & & $2.53 \pm 0.03$ & $2.39 \pm 0.04$ & \\
\hline HSI & $1.6 \pm 0.04$ & $1.4 \pm 0.04$ & $* *$ & $1.5 \pm 0.06$ & $1.2 \pm 0.05$ & $* *$ \\
\hline MSI & - & - & & $34.0 \pm 0.63$ & $34.8 \pm 0.34$ & \\
\hline MFI & $1.5 \pm 0.07$ & $1.3 \pm 0.07$ & & $1.5 \pm 0.06$ & $1.2 \pm 0.06$ & \\
\hline FCR & $1.7 \pm 0.13$ & $1.6 \pm 0.12$ & & $1.7 \pm 0.14$ & $1.3 \pm 0.05$ & * \\
\hline
\end{tabular}

Mean \pm SEM. $\mathrm{N}=4$ for SGR, CF and FCR; $\mathrm{N}=80$ for HSI and MFI; N = 12 for MSI. BW: body weight. SGR: specific growth rate $\left[100 \cdot\left(\ln\right.\right.$ final BW-ln initial BW)] days $^{-1}$. Condition Factor $=100 \cdot \mathrm{BW} / \mathrm{TL}^{3}$. HSI: Hepatosomatic Index $=\left[\mathrm{g}\right.$ liver $\left.\cdot 100 \mathrm{~g} \mathrm{B.W.}{ }^{-1}\right]$. MSI: Muscle-somatic Index [g muscle $\left.\cdot 100 \mathrm{~g} \mathrm{B.W.}{ }^{-1}\right]$. MFI: Mesenteric fat Index [g fat $100 \mathrm{~g}$ B.W. $\left.{ }^{-1}\right]$. FCR: Feed conversion rate $=\left[\right.$ feed eaten $\cdot$ weight gain $\left.{ }^{-1}\right]$. Significant differences by Student's $t$-test: $\left.{ }^{*}\right) p<0.05 ;(* *) p<0.01 ;(* *) p<0.001$.

The proximal composition, RNA, and DNA concentrations of white muscle after rBGH injection on fingerlings and juveniles are presented in Table 2. A significant decrease of lipids was observed at both ages/sizes in the experimental fish $(p<0.001)$ compared to their respective control groups. The rBGH group of juveniles practically doubled $(p<0.01)$ the glycogen reserves in white muscle and showed significantly increased RNA concentration $(p<0.001)$, which resulted in an increase of the RNA/DNA ratio in this group $(p<0.01)$. Notwithstanding, these changes in white muscle glycogen and RNA were not observed in fingerlings.

The proximal composition in red muscle and liver was also analysed in juveniles (Table 3). The decrease of lipid concentration was also observed in liver and red muscle of rBGH group, but the differences were only significant in liver $(p<0.05)$. As in white muscle, the red muscle glycogen was significantly increased in the rBGH-injected fish $(p<0.01)$, but on the contrary in liver this reserve was decreased $(p<0.05)$ compared to the controls.

The isotopic composition of white muscle and its reserves were significantly modified by rBGH administration in both fingerlings and juveniles (Table 4 ). $\delta^{13} \mathrm{C}$ values of muscle, lipid and glycogen reserves were significantly increased in rBGH-treated groups in fingerlings and juveniles, revealing turnover differences of these reserves between experimental and control groups. Furthermore, $\delta^{15} \mathrm{~N}$ of muscle and of its protein was significantly reduced in both fingerlings $(p<0.05)$ and juveniles $(p<0.01)$, and as a consequence, the nitrogen fractionation was significantly reduced, indicating a better use of the protein diet in rBGH groups. 
Table 2. Proximal composition, RNA and DNA contents and CS and COX activities in white muscle after 6 or 9 weeks of rBGH injection on gilthead sea bream fingerlings and juveniles, respectively.

\begin{tabular}{|c|c|c|c|c|c|}
\hline & \multicolumn{2}{|c|}{ Fingerlings } & \multicolumn{2}{|c|}{ Juveniles } & \\
\hline & Control & rbGH & Control & rbGH & \\
\hline \multicolumn{6}{|l|}{ Composition } \\
\hline Protein (\% w.w.) & $19.2 \pm 0.17$ & $19.2 \pm 0.18$ & $19.8 \pm 0.28$ & \multicolumn{2}{|c|}{$19.7 \pm 0.22$} \\
\hline Lipids (\% w.w.) & $2.2 \pm 0.12$ & $1.5 \pm 0.08 \quad * * *$ & $2.4 \pm 0.12$ & $1.5 \pm 0.10$ & $* * *$ \\
\hline Glycogen (\% w.w.) & $0.15 \pm 0.01$ & $0.17 \pm 0.02$ & $0.25 \pm 0.04$ & $0.46 \pm 0.05$ & ** \\
\hline Wet weight (\%) & $78.5 \pm 0.14$ & $78.5 \pm 0.14$ & $75.1 \pm 0.26$ & $76.5 \pm 0.22$ & $*$ \\
\hline RNA ( $\mu \mathrm{g} / \mathrm{mg}$ prot) & $6.7 \pm 0.19$ & $7.3 \pm 0.56$ & $4.1 \pm 0.09$ & $5.4 \pm 0.20$ & $* * *$ \\
\hline DNA ( $\mu \mathrm{g} / \mathrm{mg}$ prot) & $1.46 \pm 0.07$ & $1.42 \pm 0.13$ & $0.9 \pm 0.03$ & \multicolumn{2}{|c|}{$1.0 \pm 0.05$} \\
\hline RNA/DNA & $4.7 \pm 0.27$ & $4.8 \pm 0.28$ & $4.7 \pm 0.18$ & $5.7 \pm 0.32$ & $* *$ \\
\hline \multicolumn{6}{|l|}{ Enzyme activities } \\
\hline $\mathrm{CS}^{1}$ & $77.7 \pm 3.50$ & $81.0 \pm 5.07$ & $42.3 \pm 1.98$ & \multicolumn{2}{|c|}{$44.7 \pm 1.81$} \\
\hline $\operatorname{cox}^{1}$ & $27.5 \pm 1.25$ & $26.9 \pm 2.19$ & $15.1 \pm 0.56$ & \multicolumn{2}{|c|}{$14.5 \pm 0.83$} \\
\hline $\mathrm{COX} / \mathrm{CS}$ & $0.35 \pm 0.02$ & $0.34 \pm 0.03$ & $0.37 \pm 0.03$ & \multicolumn{2}{|c|}{$0.33 \pm 0.02$} \\
\hline
\end{tabular}

Mean \pm SEM. $\mathrm{N}=10$ for fingerlings and $\mathrm{N}=12$ for juveniles. ${ }^{1} \mathrm{mUI} / \mathrm{mg}$ prot. CS: citrate synthase; COX: cytochrome-c-oxidase. Significant differences by Student's $t$-test: $\left.\left.{ }^{*}\right) p<0.05 ;\left({ }^{* *}\right) p<0.01 ;{ }^{* * *}\right) p<0.001$.

Table 3. Proximal composition and metabolic enzyme activities in red muscle and liver after 9 weeks of rBGH injection on gilthead sea bream juveniles.

\begin{tabular}{|c|c|c|c|c|c|c|}
\hline & \multicolumn{5}{|c|}{ Juveniles } & \\
\hline & \multicolumn{2}{|c|}{ Red Muscle } & \multicolumn{4}{|c|}{ Liver } \\
\hline & Control & rbGH & & Control & rbGH & \\
\hline \multicolumn{7}{|l|}{ Composition } \\
\hline Protein (\% w.w.) & $15.7 \pm 1.29$ & $16.9 \pm 1.49$ & & $12.5 \pm 0.62$ & $12.5 \pm 0.79$ & \\
\hline Glycogen (\% w.w.) & $0.45 \pm 0.06$ & $0.75 \pm 0.02$ & $* *$ & $12.5 \pm 0.85$ & $9.9 \pm 0.51$ & * \\
\hline Lipids (\% w.w.) & $19.2 \pm 0.87$ & $14.4 \pm 1.70$ & & $16.8 \pm 0.77$ & $13.6 \pm 0.97$ & * \\
\hline \multicolumn{7}{|l|}{ Enzyme activities } \\
\hline $\mathrm{CS}^{1}$ & $467 \pm 23.1$ & $515 \pm 51.2$ & & $34.3 \pm 1.76$ & $40.1 \pm 1.37$ & * \\
\hline $\operatorname{cox}^{1}$ & $131 \pm 10.3$ & $125 \pm 9.92$ & & $121.8 \pm 3.8$ & $114.4 \pm 5.20$ & \\
\hline $\mathrm{HOAD}^{2}$ & & & & $5.09 \pm 0.35$ & $5.14 \pm 0.20$ & \\
\hline $\mathrm{LDH}^{1}$ & & & & $8.01 \pm 0.68$ & $8.07 \pm 0.41$ & \\
\hline ALAT $^{1}$ & & & & $45.6 \pm 1.22$ & $39.4 \pm 1.01$ & ** \\
\hline ASAT $^{1}$ & & & & $77.6 \pm 4.53$ & $81.3 \pm 3.16$ & \\
\hline
\end{tabular}

Mean \pm SEM. $\mathrm{N}=12$. Significant differences by Student's $t$-test: $\left({ }^{*}\right) p<0.05 ;\left({ }^{* *}\right) p<0.01 .{ }^{1} \mathrm{mUI} / \mathrm{mg}$ protein. ${ }^{2} \mathrm{UI} / \mathrm{mg}$ protein. CS: citrate synthase; COX: cytochrome-c-oxidase; LDH: lactate dehydrogenase; ALAT: alanine transaminase; ASAT: Aspartate transaminase.

Table 4. Isotopic composition $\left({ }^{15} \mathrm{~N} /{ }^{13} \mathrm{C}\right)$ in white muscle after 6 or 9 weeks of rBGH injection on gilthead sea bream fingerlings and juveniles.

\begin{tabular}{|c|c|c|c|c|c|c|}
\hline & \multicolumn{2}{|c|}{ Fingerlings } & \multicolumn{4}{|c|}{ Juveniles } \\
\hline & Control & rbGH & & Control & rbGH & \\
\hline$\delta^{13}$ C-muscle & $-20.60 \pm 0.03$ & $-20.45 \pm 0.03$ & ** & $-20.49 \pm 0.12$ & $-19.77 \pm 0.06$ & **** \\
\hline$\delta^{13}$ C-lipid & $-26.15 \pm 0.05$ & $-25.97 \pm 0.06$ & $*$ & $-25.61 \pm 0.02$ & $-25.46 \pm 0.03$ & $* * *$ \\
\hline$\delta^{13}$ C-glycogen & $-20.91 \pm 0.14$ & $-20.60 \pm 0.14$ & & $-19.93 \pm 0.19$ & $-19.41 \pm 0.17$ & $*$ \\
\hline$\delta^{13} \mathrm{C}$-protein & $-21.51 \pm 0.05$ & $-21.89 \pm 0.36$ & & $-20.49 \pm 0.02$ & $-20.56 \pm 0.05$ & \\
\hline$\delta^{15} \mathrm{~N}$-muscle & $12.19 \pm 0.04$ & $12.13 \pm 0.06$ & & $9.64 \pm 0.11$ & $9.24 \pm 0.06$ & $* *$ \\
\hline$\delta^{15} \mathrm{~N}$-protein & $13.47 \pm 0.06$ & $13.19 \pm 0.09$ & * & $10.59 \pm 0.10$ & $10.22 \pm 0.07$ & $* *$ \\
\hline$\Delta^{15} \mathrm{~N}$-muscle ${ }^{1}$ & $2.57 \pm 0.04$ & $2.51 \pm 0.07$ & & $0.02 \pm 0.11$ & $-0.38 \pm 0.06$ & $* *$ \\
\hline$\Delta^{15} \mathrm{~N}$-protein ${ }^{1}$ & $3.73 \pm 0.05$ & $3.45 \pm 0.09$ & * & $0.85 \pm 0.10$ & $0.48 \pm 0.07$ & $*$ \\
\hline
\end{tabular}

Mean \pm SEM. $N=10$ for fingerlings and N $=12$ for juveniles. Significant differences by Student's $t$-test: $\left({ }^{*}\right) p<0.05 ;\left({ }^{* *}\right) p<0.01$; ${ }^{(* * *)} p<0.001 .{ }^{1} 15 \mathrm{~N}$ Fractionation $=\delta^{15} \mathrm{~N}$ (in muscle or protein fraction) $-\delta^{15} \mathrm{~N}$ diet. Diet: $\delta^{15} \mathrm{~N}$ is $9.62 \pm 0.05$ in the whole diet and $9.74 \pm 0.05$ in the dietary protein fraction. 


\subsection{Enzyme Activities and Protein Expression}

The activities of the main antioxidants enzymes, catalase (CAT), superoxide dismutase (SOD) and two glutathione forms, glutathione peroxidase and glutathione reductase (GPx and GR) in liver are showed in Figure 1. The enzyme activity of CAT was significantly decreased in rBGH group $(p<0.01)$, meanwhile SOD showed a tendency to increase in this group compared to the control fish. GR significantly increased $(p<0.05)$ and GPx decreased $(p<0.05)$ in rBGH-injected group compared to control group.

\section{CAT}

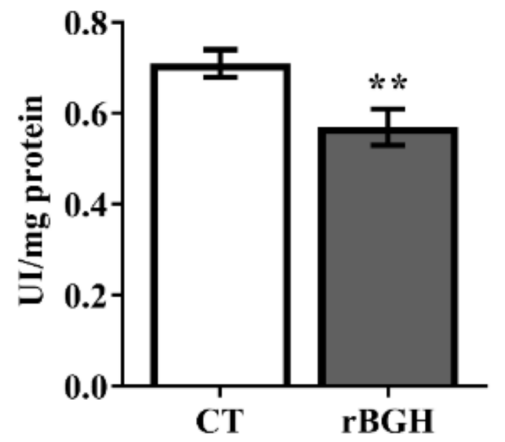

GR

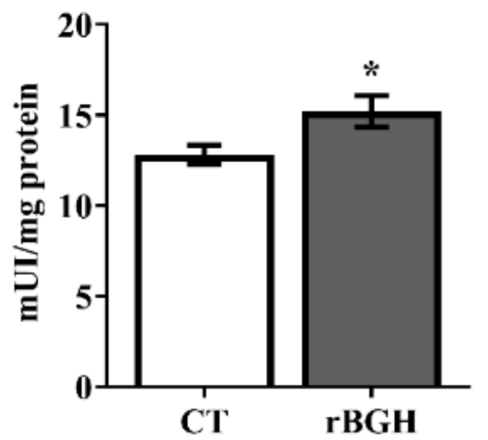

\section{SOD}

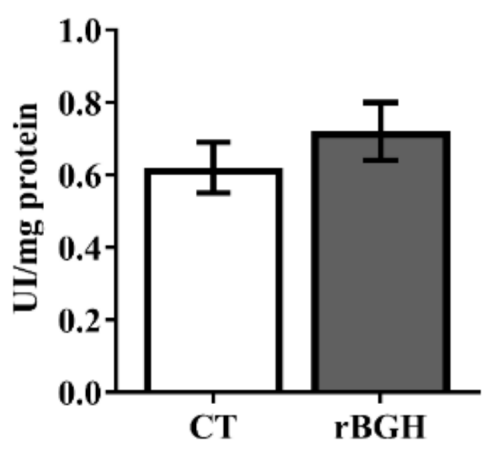

GPX

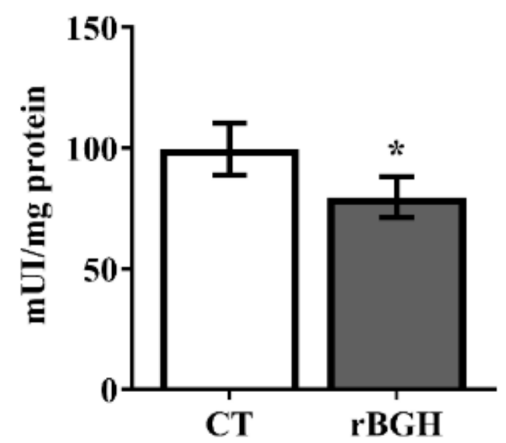

Figure 1. Enzyme activities of redox metabolism in liver after 9 weeks of rBGH injection on gilthead sea bream juveniles. Data are shown as means \pm SEM $(n=12)$. Significant differences between control and rBGH groups for each enzyme were determined by Student's $t$-test and are marked with $\left(^{*}\right) p<0.05$ or $\left(^{* *}\right) p<0.01$. Abbreviations: catalase (CAT), superoxide dismutase (SOD), glutathione reductase (GR) and glutathione peroxidase (GPX).

In liver, the enzyme activity of citrate synthase (CS) significantly increased $(p<0.05)$ and that of alanine transaminase (ALAT) significantly decreased $(p<0.01)$ in rBGH-injected juveniles compared to the control group, but no changes were observed in hydroxyacyl CoA dehydrogenase (HOAD), lactate dehydrogenase (LDH) or aspartate transaminase (ASAT) (Table 3). The enzyme activities of CS and cytochrome-c-oxidase (COX), the two energy metabolism enzymes, were not modified by rBGH injection in the white muscle of fingerlings and juveniles (Table 2) nor in the red muscle of juveniles (Table 3). When the protein expression of these enzymes was analysed in both muscles of juvenile fish, only a significant lower protein expression of COX $(p<0.001)$ was observed in white muscle (Figure 2). In red muscle of the rBGH group, a significant lower expression of regulatory factor PGC1-alpha $(p<0.05)$ was also found (Figure 2). 
WM CS

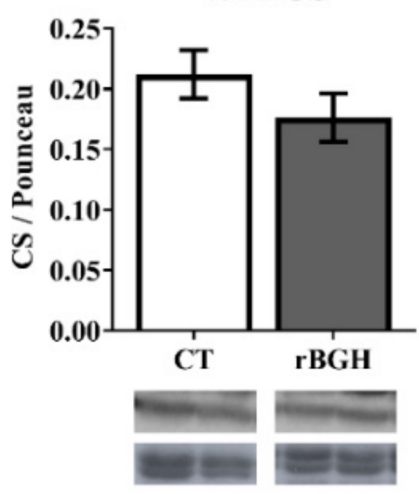

WM COX4a

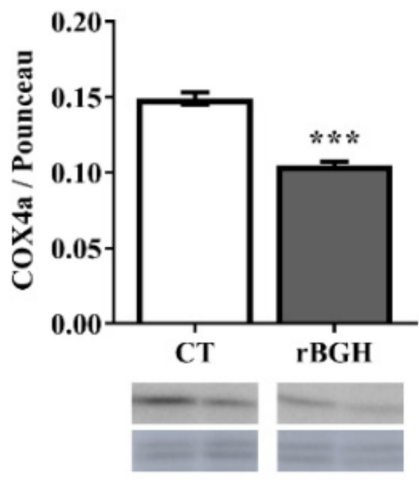

WM PGC1 $\alpha$

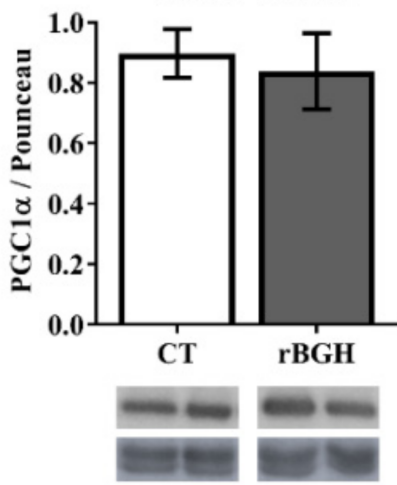

RM CS

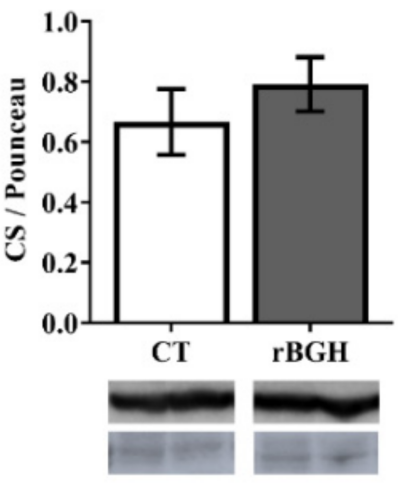

RM COX4a

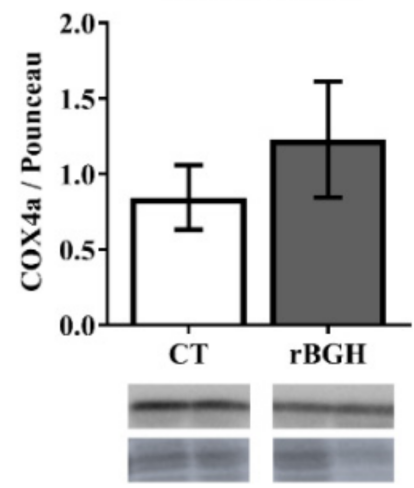

RM PGC1 $\alpha$

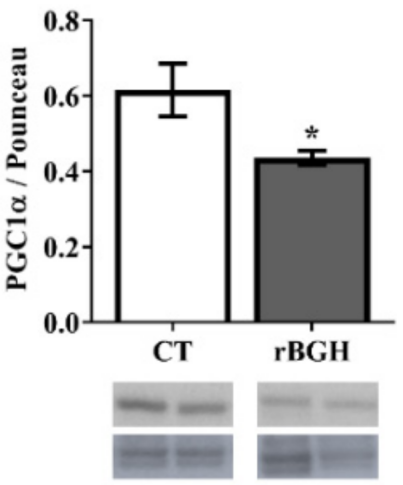

Figure 2. Protein expression of citrate synthase (CS), cytochrome-c-oxidase (COX4a) and peroxisome proliferator-activated receptor gamma coactivator 1-alpha (PGC1 $\alpha$ ) in white and red muscle after 9 weeks of rBGH injection on gilthead sea bream juveniles. Specific immunoreactive bands were normalized to total protein staining with Ponceau $S$ and shown as means \pm SEM $(n=6)$. Intermembrane variability was normalized using a random sample as a protein load control (more details in Supplementary materials: Figure S2). Significant differences between control and rBGH groups for each protein were determined by Student's $t$-test and are marked with $\left(^{*}\right) p<0.05 ;\left({ }^{* *}\right) p<0.001$. Abbreviations: WM (white muscle) and RM (red muscle).

\subsection{White Muscle Proteome}

When analysing the proteome, the number of spots detected in the white muscle of all samples of gilthead sea bream juveniles ranged between 1029 for rBGH group and 1025 for control group. Three-hundred candidate spots selected for mass spectrometry (MS) analysis presented a 2 -fold change or an intensity exceeding $0.1 \%$ (relative to total intensity). Of these, 43 protein spots showed significant differences ( $t$-test, $p<0.05$ ) between 
the rBGH and control groups, being 25 down-regulated and 18 up-regulated in response to rBGH injection. The MS characterization of these proteins, followed by MASCOT database searches, resulted in 7 non-detected proteins (corresponding to trypsin and keratin residues) and 36 identified protein spots (Table 5), which corresponded to 13 protein sequences that have been already reported in teleost species. The results of Gene Ontology (GO) enrichment analysis indicated that most of these proteins (8) were grouped in a single cluster, "carbohydrate metabolic process" (GO: 00005975) (Figure 3A), and most of them were down-regulated the in white muscle of the $\mathrm{rBGH}$-treated group, as it is shown in the heat map of the significantly different proteins presented in Figure 3B.

(A)

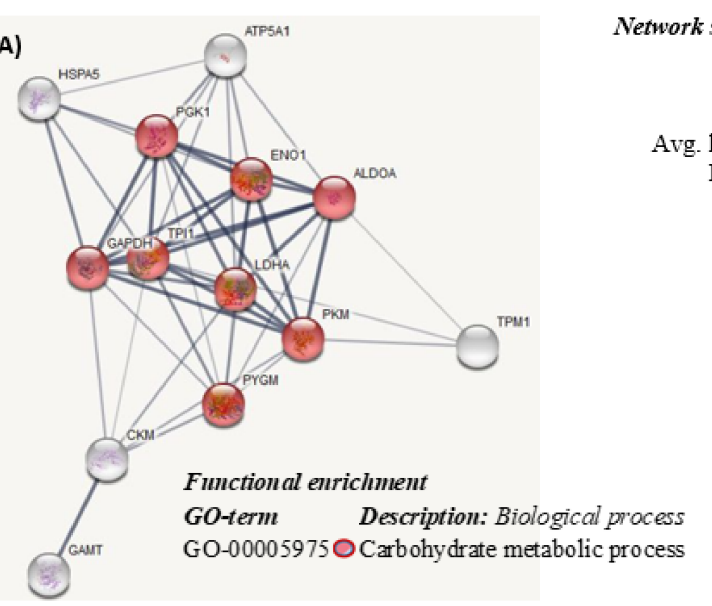

(B)
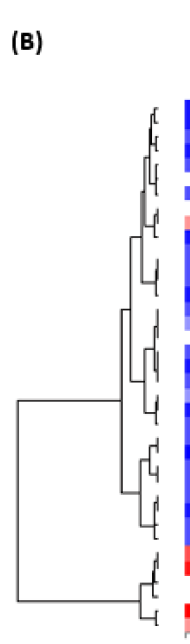

number of nodes: 13 Number of edges: 49 Average node degree: 7.54 . local clustering coefficient: 0.846 PP1 enrichment p-value: $<1.0^{-16}$ $\begin{array}{ll}\text { Count in network } & \text { False discovery rate } \\ 8 \text { of } 457 & 1.28^{-9}\end{array}$

Figure 3. White muscle proteomic profile of differentially expressed proteins between rbGH group and control group of gilthead sea bream. (A) The network analysis of protein-protein interactions among proteins grouped into 1 functional category, according to Gene Ontology enrichment analysis by GOEAST. In this network, nodes are proteins, the thickness of the lines indicates the degree of confidence prediction of the interaction, according to the STRING databases. The average of local clustering coefficient was 0.846 for "Carbohydrate metabolic process" (GO: 0005975, $p$-value: 1.0 ${ }^{-16}$ ) (see Supplementary materials: Table S1). (B) Heat map of the hierarchical clustering of the relative abundance of differentially expressed proteins between the white muscle of rbGH group and control group (Perseus program). Every line represents one independent sample of each group, while the different protein spots are represented by individual rows. Red indicates high levels of expression while blue represents low levels. The intensity of the colours represents the relative abundance. Raw data of each spot are included in Supplementary materials (Table S2). Protein acronyms correspond to Gene Symbol (see Table 5 for details). 
Table 5. Identification of the 37 differentially expressed proteins of white muscle after 9 weeks of rBGH injection on gilthead sea bream juveniles.

\begin{tabular}{|c|c|c|c|c|c|c|c|c|c|c|c|c|}
\hline${ }^{\mathrm{a}} \mathrm{SPOT}$ & $\begin{array}{l}\text { Accession } \\
\text { No. }\end{array}$ & b Protein Name & Species & ${ }^{\mathrm{c}}$ Symbol & $\begin{array}{c}\text { Theorical } \\
\text { KDa/pI }\end{array}$ & $\begin{array}{c}\text { Observed } \\
\text { Kda/pI }\end{array}$ & ${ }^{d}$ score & $\begin{array}{l}\text { e Peptides } \\
\text { (Unique) }\end{array}$ & ${ }^{\mathrm{f}} \mathrm{SC}(\%)$ & ${ }^{\mathrm{g}} \mathrm{FC}$ & ${ }^{\mathrm{h}} p$-Value & UniprotKB \\
\hline \multirow{2}{*}{\multicolumn{13}{|c|}{$\begin{array}{l}\text { Cellular Metabolic Process: GO: } 0044237 \\
\text { Carbohydrate Metabolic Process: GO: } 0005975 \text { ( } p \text {-Value: } 2.3^{-47} \text { ) }\end{array}$}} \\
\hline & & & & & & & & & & & & \\
\hline 125 & I3JBN0 & Alpha-1,4 glucan phosphorylase & Oreochromis niloticus & PYGM & $97.1 / 7.1$ & $95.0 / 8.5$ & 233.68 & $28(2)$ & 34.68 & 0.24 & 0.0102 & P11217 \\
\hline 538 & I3JBN0 & Alpha-1,4 glucan phosphorylase & Oreochromis niloticus & PYGM & $97.1 / 7.1$ & $96.0 / 6.9$ & 991.63 & $35(6)$ & 40.50 & 1.39 & 0.0422 & P11217 \\
\hline 540 & I3JBN0 & Alpha-1,4 glucan phosphorylase & Oreochromis niloticus & PYGM & $97.1 / 7.1$ & $96.0 / 6.9$ & 991.11 & $33(5)$ & 39.07 & 0.74 & 0.0026 & P11217 \\
\hline 117 & Q4SFP9 & $\begin{array}{l}\text { Alpha-1,4 glucan phosphorylase } \\
\text { (Fragment) }\end{array}$ & Tetraodon nigroviridis & PYGM & $97.2 / 6.9$ & $95.0 / 7.3$ & 1085.21 & $36(1)$ & 41.74 & 0.40 & 0.0003 & P11217 \\
\hline 541 & G3QBP8 & Alpha-1,4 glucan phosphorylase & Gasterosteus aculeatus & PYGM & $83.5 / 6.9$ & $97.0 / 6.8$ & 100.04 & $7(2)$ & 13.36 & 1.51 & 0.0001 & P11217 \\
\hline 124 & I3JBN0 & Alpha-1,4 glucan phosphorylase & Oreochromis niloticus & PYGM & $97.1 / 7.1$ & $96.0 / 8.3$ & 524.38 & $36(3)$ & 40.26 & 0.32 & 0.0117 & P11217 \\
\hline 118 & A0A147AQX3 & Alpha-1,4 glucan phosphorylase & Fundulus heteroclitus & PYGM & $102.7 / 7.3$ & $97.0 / 7.4$ & 907.09 & $33(3)$ & 37.95 & 0.34 & 0.0285 & P11217 \\
\hline 126 & A0A147AQ̄X3 & Alpha-1,4 glucan phosphorylase & Fundulus heteroclitus & PYGM & $102.7 / 7.3$ & $96.0 / 8.6$ & 304.63 & $31(4)$ & 33.22 & 0.45 & 0.0275 & P11217 \\
\hline 875 & I3JBN0 & Alpha-1,4 glucan phosphorylase & Oreochromis niloticus & PYGM & $97.1 / 7.1$ & $109.0 / 6.8$ & 309.30 & $32(3)$ & 38.36 & 0.23 & 0.0211 & P11217 \\
\hline 494 & I3KL67 & Phosphoglycerate kinase & Oreochromis niloticus & PGK1 & $44.5 / 6.9$ & $50.0 / 6.9$ & 905.26 & $20(3)$ & 48.68 & 0.70 & 0.0244 & P00558 \\
\hline 157 & Q155W8 & $\begin{array}{l}\text { Glyceraldehyde-3-phosphate } \\
\text { dehydrogenase }\end{array}$ & Sparus aurata & GAPDH & $36.0 / 8.4$ & $20.2 / 8.2$ & 705.47 & $19(6)$ & 72.67 & 0.46 & 0.0341 & P04406 \\
\hline 158 & Q155W8 & $\begin{array}{l}\text { Glyceraldehyde-3-phosphate } \\
\text { dehydrogenase }\end{array}$ & Sparus aurata & GAPDH & $36.0 / 8.4$ & $24.9 / 7.8$ & 463.46 & $15(7)$ & 69.07 & 0.29 & 0.0548 & P04406 \\
\hline 84 & Q155W8 & $\begin{array}{l}\text { Glyceraldehyde-3-phosphate } \\
\text { dehydrogenase }\end{array}$ & Sparus aurata & GAPDH & $36.0 / 8.4$ & $67.0 / 8.2$ & 1083.31 & $15(7)$ & 67.27 & 0.34 & 0.0289 & P04406 \\
\hline 625 & Q155W8 & $\begin{array}{l}\text { Glyceraldehyde-3-phosphate } \\
\text { dehydrogenase }\end{array}$ & Sparus aurata & GAPDH & $36.0 / 8.4$ & $25.3 / 8.0$ & 401.04 & $11(11)$ & 60.96 & 0.53 & 0.0227 & P04406 \\
\hline 905 & Q155W8 & $\begin{array}{l}\text { Glyceraldehyde-3-phosphate } \\
\text { dehydrogenase }\end{array}$ & Sparus aurata & GAPDH & $36.0 / 8.4$ & $70.0 / 7.9$ & 33.25 & $6(6)$ & 32.73 & 0.18 & 0.0368 & P04406 \\
\hline 22 & Q155W8 & $\begin{array}{l}\text { Glyceraldehyde-3-phosphate } \\
\text { dehydrogenase }\end{array}$ & Sparus aurata & GAPDH & $36.0 / 8.4$ & $44.0 / 6.8$ & 126.74 & $15(6)$ & 57.06 & 2.40 & 0.0285 & P04406 \\
\hline 530 & Q155W8 & $\begin{array}{l}\text { Glyceraldehyde-3-phosphate } \\
\text { dehydrogenase }\end{array}$ & Sparus aurata & GAPDH & $36.0 / 8.4$ & $87.0 / 8.1$ & 100.59 & $10(5)$ & 49.25 & 0.14 & 0.0293 & P04406 \\
\hline 734 & Q155W8 & $\begin{array}{l}\text { Glyceraldehyde-3-phosphate } \\
\text { dehydrogenase }\end{array}$ & Sparus aurata & GAPDH & $36.0 / 8.4$ & $108 / 8.2$ & 83.44 & $12(7)$ & 62.46 & 0.65 & 0.0081 & P04406 \\
\hline 37 & O13276 & L-lactate dehydrogenase A chain & Sphyraena argentea & LDHA & $36.4 / 8.0$ & $69.0 / 6.9$ & 942.71 & $17(2)$ & 37.95 & 0.37 & 0.0176 & P00338 \\
\hline 728 & O13276 & L-lactate dehydrogenase A chain & Sphyraena argentea & LDHA & $36.4 / 8.0$ & $44.0 / 6.9$ & 557.60 & $12(3)$ & 32.23 & 0.50 & 0.0348 & P00338 \\
\hline 726 & O13276 & L-lactate dehydrogenase A chain & Sphyraena argentea & LDHA & $36.4 / 8.0$ & $41.0 / 6.9$ & 868.73 & $14(1)$ & 34.34 & 0.40 & 0.0094 & P00338 \\
\hline 727 & O13276 & L-lactate dehydrogenase A chain & Sphyraena argentea & LDHA & $36.4 / 8.0$ & $48.0 / 6.9$ & 559.10 & $14(4)$ & 34.34 & 1.92 & 0.0279 & P00338 \\
\hline 508 & A0A147AE36 & Alpha-enolase & Fundulus heteroclitus & ENO1 & $47.5 / 6.8$ & $64.0 / 7.3$ & 1028.05 & $20(1)$ & 58.29 & 0.55 & 0.0220 & P06733 \\
\hline 903 & A0A147AE36 & Alpha-enolase & Fundulus heteroclitus & ENO1 & $47.5 / 6.8$ & $65.0 / 7.7$ & 865.01 & $15(1)$ & 47.24 & 0.40 & 0.0322 & P06733 \\
\hline 36 & A0A146XBN2 & Alpha-enolase & Fundulus heteroclitus & ENO1 & $46.4 / 6.7$ & $65.0 / 6.6$ & 901.83 & $15(1)$ & 50.70 & 0.53 & 0.0086 & P06733 \\
\hline 94 & A0A0F8AK35 & Pyruvate kinase & Larimichthys crocea & PKM & $58.2 / 7.7$ & $73.0 / 8.5$ & 819.93 & $15(4)$ & 36.04 & 0.39 & 0.0216 & P14618 \\
\hline 523 & Q8QGU8 & Pyruvate kinase & Takifugu rubripes & PKM & $58.0 / 7.9$ & $74.0 / 7.6$ & 657.85 & $18(2)$ & 34.53 & 0.44 & 0.0037 & P14618 \\
\hline
\end{tabular}


Table 5. Cont.

\begin{tabular}{|c|c|c|c|c|c|c|c|c|c|c|c|c|}
\hline a SPOT & $\begin{array}{c}\text { Accession } \\
\text { No. }\end{array}$ & b Protein Name & Species & c Symbol & $\begin{array}{c}\text { Theorical } \\
\text { KDa/pI }\end{array}$ & $\begin{array}{c}\text { Observed } \\
\text { Kda/pI }\end{array}$ & ${ }^{d}$ score & $\begin{array}{l}\text { e Peptides } \\
\text { (Unique) }\end{array}$ & ${ }^{\mathrm{f}} \mathrm{SC}(\%)$ & ${ }^{g}$ FC & ${ }^{\mathrm{h}} p$-Value & UniprotKB \\
\hline 100 & A0A0F8AK35 & Pyruvate kinase & Larimichthys crocea & PKM & $58.2 / 7.7$ & $74.0 / 8.0$ & 195.81 & $8(1)$ & 21.51 & 0.22 & 0.0120 & P14618 \\
\hline 500 & H2TGY6 & Fructose-bisphosphate aldolase & Takifugu rubripes & ALDOA & $39.6 / 8.3$ & $54.0 / 7.7$ & 283.00 & $12(1)$ & 40.22 & 0.56 & 0.0051 & P04075 \\
\hline 764 & A0A1A8A8E2 & Triosephosphate isomerase & Nothobranchius furzeri & TPI1 & $26.5 / 7.3$ & $29.0 / 7.3$ & 69.63 & $7(7)$ & 36.84 & 0.29 & 0.0010 & P60174 \\
\hline \multicolumn{13}{|c|}{ 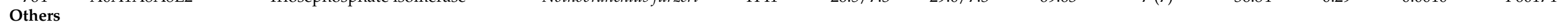 } \\
\hline 279 & Q71N41 & Guanidinoacetate N-methyltransferase & Danio rerio & GAMT & $26.7 / 6.3$ & $33.0 / 6.0$ & 513.76 & $5(2)$ & 28.21 & 1.50 & 0.0138 & Q14353 \\
\hline 493 & A0A146WHL4 & Creatine kinase M-type & Fundulus heteroclitus & CKM & $42.8 / 6.8$ & $53.0 / 6.9$ & 1117.72 & $15(1)$ & 41.10 & 0.46 & 0.0123 & P06732 \\
\hline 206 & A0A0F8AHC2 & Glucose-regulated protein & Larimichthys crocea & HSPA5 & $82.3 / 5.6$ & $95.0 / 5.6$ & 152.41 & $19(3)$ & 29.88 & 0.64 & 0.0088 & P11021 \\
\hline 717 & A0A0F6MX10 & ATP synthase subunit alpha & Sparus aurata & ATP5F1A & $59.6 / 9.1$ & $68.0 / 6.9$ & 94.37 & $15(15)$ & 38.66 & 0.15 & 0.0185 & P25705 \\
\hline 681 & D6PVP3 & Tropomyosin & Epinephelus coioides & TPM1 & $32.7 / 4.7$ & $45.0 / 4.7$ & 183.97 & $17(2)$ & 46.13 & 0.34 & 0.0080 & P09493 \\
\hline
\end{tabular}

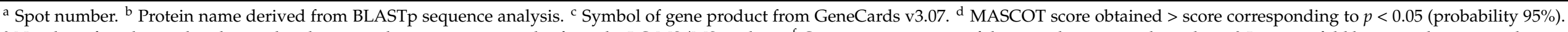

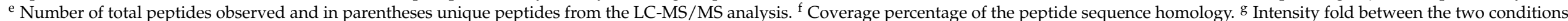

(rBGH/control: $>0$, up-regulated; $<0$, down-regulated). ${ }^{\mathrm{h}} t$-test $(n=6)$. 


\section{Discussion}

This study is a continuation of the research conducted previously in our group to investigate the effect of rBGH on the GH/IGF axis and the regulation of myogenesis and osteogenesis in fingerlings [11] and juveniles [12] of gilthead sea bream. In the present work, the final body weight, SGR and somatic indexes of fingerlings are the same as those reported in Vélez et al. (2018) [11], but in juveniles, they correspond to samplings performed 9 weeks after injection, while in Vélez et al. (2019) [12], these growth parameters were obtained at 6 and 12 weeks after injection. The time points used, 6 and 9 weeks, were selected taking into account previous studies, as discussed in Vélez et al., (2019) [12]. In both experiments, we found an improvement of somatic growth that is in accordance with the observations of other authors made from fish species injected with $\mathrm{rBGH}[2,8,38,39]$. Interestingly, we did not observe changes in CF and MSI, suggesting a harmonious and proportional growth of individuals, in contrast to what it was observed in coho salmon under similar experimental conditions [40]. Notwithstanding, the dose of GH used, the species and the fish age may determine different effects that would explain the variety of results among studies. In fact, we were able to observe decreased CF at 6 weeks after administration of rBGH [12], which subsequently disappeared, as we have observed in the 9-week results, and that was maintained up to week 12. Moreover, the stimulation of growth determined a significant reduction of FCR in rBGH-treated juveniles, suggesting an improvement of the food conversion efficiency, as other authors previously reported in other species [41,42].

Although the decrease on mesenteric fat (MFI) and red muscle lipid concentration on rBGH fish was not significant, the clear effects in the white muscle of both fingerlings and juveniles and in the liver of juveniles after rBGH injection verified the lipolytic effect of this hormone, in agreement with previous observations in other fish species [19,43-45]. The lipolytic effect of GH has been widely described, but few studies in fish have determined the reduction of the lipid reserves in target tissues. In this sense, the rBGH treatment induced a decrease in the subcutaneous fat layer and in plasma triglycerides levels of gilthead sea bream fingerlings [11], suggesting an enhancement of lipolytic activity. Moreover, increased release of glycerol was found in isolated hepatocytes, adipocytes and primary cultured myocytes extracted from rBGH-injected juveniles [12]. This key metabolic action of GH was also observed in isolated adipocytes incubated with homologous GH [46], and it is at least partly mediated via the hormone-sensitive lipase (HSL) activity [46-48]. In spite of the lipolytic role of $\mathrm{rBGH}$, the activity of the liver HOAD, a fatty acid $\beta$-oxidation key enzyme, was not affected at 9 weeks post-injection in juveniles. Under the conditions of this study, the livers of the experimental animals had less lipids than those in the control group, which would indicate that the lipolytic effect of rBGH would have finished at 9 weeks or that other enzymes, such as HSL, would be activated [12], as it occurs in mammals [18]. This increased lypolitic activity may be viewed as a mean of switching substrate metabolism from glucose and protein utilization to lipid oxidation, as pointed out in mammals [18].

The changes of isotopic composition of the tissue reserves allowed us to deepen more in the use of these reserves, their turnover, and the resulting crosstalk among tissues such as liver and muscle. Thus, when the energy needs of gilthead sea bream vary as it happens during exercise [36,49], or when changes in the feeding conditions are induced [37], the tissues isotopic footprint is modified, revealing changes in the recycling of reserves and the allocation of $\mathrm{C}$ or $\mathrm{N}$ between diet and tissue reserves. Accordingly, the significant enrichment of the $\delta^{13} \mathrm{C}$ observed in white muscle of both $\mathrm{rBGH}$-injected fish groups (i.e., fingerlings and juveniles) would be a consequence of the reduction in white muscle lipids, as we have demonstrated in other demanding energy conditions, such as swimming activity [36]. Moreover, the turnover of white muscle glycogen increased (i.e., increase in $\delta^{13} \mathrm{C}$-glycogen) in juveniles, which would contribute to change the fingerprint of $\delta^{13} \mathrm{C}$ of muscle. The significant enrichment of the $\delta^{13} \mathrm{C}$ from the glycogen reserve, and the increase in concentration of this metabolite in both muscles would indicate a turnover modification of this reserve with a positive balance for the synthesis and/or decrease of its 
degradation as a consequence of rBGH injection. In this way, GH and IGF-I treatments, both singly or in combination, significantly increased the glycogen content of hepatocytes isolated from Arctic char [27], in agreement with that observed in mammals [18]. Thus, the present results showed that there is a shift in the preferential use of energy substrates in response to GH treatment also in gilthead sea bream, with a greater use of lipids and a reduction in carbohydrate utilization, as observed in mammals. In the latter, sustained glucose release is dependent on gluconeogenesis from amino acids, while increased fat utilization and diminished glucose utilization by GH action also decrease the need for protein breakdown [18].

The role that GH exerts on protein metabolism in mammals is well known; it modifies protein balance by stimulating the synthesis and reducing protein degradation [18]. Although net protein growth has also been evidenced in fish species [39], there is no indication about GH direct effects on the processes of synthesis and protein degradation. Our results clearly indicated a reduction in muscle protein fractionation in juveniles of gilthead sea bream due to the injection of $\mathrm{rBGH}$, which is interpreted as a positive balance on protein growth that in turn can be associated with higher synthesis or with reduced degradation. In this sense, the reduction of hepatic ALAT in the group injected with rBGH would be another evidence of the reduction in protein recycling in this group, in agreement with that observed in other teleost injected with GH [27] or in in vitro treated hepatocytes [22]. The observed decrease in nitrogen fractionation, as a result of decreased $\delta^{15} \mathrm{~N}$, a reliable indicator of nutritional status in fish [37], implies a reduction in protein turnover and a protein sparing as we observed previously in the same species submitted to changes in diet or swimming activity [35-37,49]. Moreover, the significant increase found in muscle RNA concentration in $\mathrm{rBGH}$-injected juveniles also suggested that protein synthesis capacity was increased, as we observed in exercised gilthead sea bream [36,49]. In accordance with this result, the $20 \%$ increase in body weight in juveniles injected with $\mathrm{rBGH}$, without changes in the percentage of muscle mass or protein content, clearly indicated that there has been a net increase in protein muscle in these fish compared to the control group. Our results are in agreement with those obtained in GH-injected rainbow trout, where the GH treatment altered catabolic and anabolic processes, producing a leaner fish with a higher protein content with respect to control fish [50].

Growth, protein synthesis and many components of fuel metabolism are ATP-requiring processes that may increase energetic demands on mitochondria, but GH effects on mitochondrial function are not fully established. Here, we have observed an increase of $\mathrm{CS}$ activity in the liver of rBGH-injected juveniles, in agreement with that observed in tilapias injected with GH [51]. However, this increase was not coupled to an increase of oxidative phosphorylation because COX activity was not modified. Then, changes in mitochondrial compartments between respiratory chain (inner membrane) and tricarboxylic acid (TCA) cycle enzymes (matrix compartment) may indicate a functional adaptation of mitochondria to adjust to tissue-specific demands in response to exogenous rBGH and to the availability of energy sources. Recent studies in humans have recorded increased mitochondrial oxidative capacity and expression of mRNAs that encode mitochondrial proteins after GH exposure alone or in combination with exercise [52,53]. GH action may therefore activate proteins in the $\beta$-oxidation or TCA cycles (e.g., HOAD and CS enzymes) or other components of the mitochondrial fuel delivery and oxidation machinery [52]. In parallel, a reduction of CAT and GPx activities was found in GH-transgenic salmon [54], which could suggest a decrease in the formation of $\mathrm{H}_{2} \mathrm{O}_{2}$. Moreover, the higher activity of GR (responsible for returning GSSG to its reduced and antioxidant active form GSH) would indicate that the GSH could be directly involved in the reduction of the ROS produced by the increased lipid metabolism or that the GSH works as a reducing factor of other antioxidant enzymes such as peroxiredoxins. Indeed, in Antarctic fish, it has been observed that these enzymes represent an important line of defence against the increase in the rate of $\mathrm{H}_{2} \mathrm{O}_{2}$ formation [55]. In contrast to liver, in both red and white muscle, the activity and protein expression of CS were not modified, but a decrease in protein expression of 
COX, maintaining the enzyme activity, was induced in the white muscle of rBGH fish. This response would indicate a decoupling between the Krebs cycle and oxidative phosphorylation, perhaps to spare energy in this condition. Interestingly, this reduction in COX activity was not observed in red muscle, where the expression of the regulatory factor PGC1 $\alpha$ was reduced. It is known that this transcription factor is the master regulator of mitochondrial biogenesis in mammals [56,57], interacting with nuclear respiratory factors involved in codifying OXPHOS genes. However, information in fish about the role of PGC1 $\alpha$ in these processes is scarce [58-60].

The proteomic approach of the present study in white muscle revealed how $\mathrm{rBGH}$ injection down-regulated only the expression of proteins grouped in a single cluster, the carbohydrate metabolic process. These results are in agreement with those observed recently in the domesticated aquaculture strain of coho salmon, selected for enhanced growth [31] and characterized by unique changes in abundance of carbohydrate-processing proteins in contrast to wild type animals. The authors indicated upregulation of several enzymes involved in glycolysis, glycogenolysis, gluconeogenesis and the pentose phosphate pathway but downregulation of several proteins involved in glucose breakdown and rapid energy generation as LDH. They concluded that during the domestication process, the remodelling of muscle energy metabolism permitted increased efficiency of energy generation to support the costs of protein turnover and growth. In our case, the high number of alpha-1,4 glycan phosphorylase protein spots indicated a high turnover of the glycogen reserve in muscle stimulated by $\mathrm{rBGH}$ but accompanied with a reduction in the long-term aerobic and anaerobic glycolytic pathway, possibly due to a shift in whole-body fuel utilization, reflecting reduced carbohydrate oxidation and enhanced fat oxidation as discussed above. This allowed muscle glycogen stores to be restored. Then, the effects of $\mathrm{GH}$ on carbohydrate metabolism are complicated both in the short and long term and may be indirectly linked via the antagonism of insulin action [61].

Moreover, Causey et al. [31] also observed downregulation of calcium-regulated proteins involved in muscle contraction regulation in domesticated coho salmon versus wild type, in agreement with our results where we observed downregulated tropomyosin. Whether these changes underlie differences in muscle composition and contractile properties remains to be demonstrated. This is the first proteomic analysis approaching the effects of rBGH in fish, and the results are in agreement with the metabolic changes indicated before.

In summary, the obtained results show how the metabolic machinery of the fish changes in the face of exogenous GH administration. Globally, a change in the use of metabolites with oxidative purposes is observed, i.e., a reduction in the use of carbohydrates, increased use of lipids and protein savings resulting in enhanced somatic growth of gilthead sea bream at both fingerling and juvenile stages. Moreover, in the same line, the isotopic approach has demonstrated a reduction of protein oxidative use in rBGH-treated fish, favouring an increase of protein deposition in muscle and, thus, fish growth.

\section{Materials and Methods}

\subsection{Fish and Experimental Design}

Two experiments with different fish size were designed.

\subsubsection{Gilthead Sea Bream Fingerlings}

Two hundred fingerlings of gilthead sea bream (initial body weight $1.0 \pm 0.05 \mathrm{~g}$ ) were obtained from a commercial hatchery in the north of Spain and reared in the facilities of the Faculty of Biology at the University of Barcelona. Fish were distributed into 8 cages of $37 \mathrm{~L}$; each two cages were put together in a larger thank (4 tanks of $200 \mathrm{~L}$, each cage with 25 fish and thus, 50 fish/tank), as previously described [11]. Fish were maintained in a sea water recirculation system at $23 \pm 1{ }^{\circ} \mathrm{C}$ and photoperiod of 15L:9D h. They were fed ad libitum (near 10\% body weight/day) five times a day with a commercial diet (Gemma Diamond Skretting, Burgos, Spain). Two cages of each tank were randomly assigned to a treatment group; Control or rBGH. Fish were anesthetized (MS-222 $0.08 \mathrm{~g} / \mathrm{L}$ ) and intraperitoneally 
injected with a single dose $\left(4 \mathrm{mg} \cdot \mathrm{g}^{-1}\right.$ body weight) of rBGH (Posilac $\odot$, Elanco Animal Health, Eli Lilly and Company) diluted 1:4 with sesame oil (Sigma-Aldrich, Tres Cantos, Spain) or with the same volume of sesame oil for the controls. After 6 weeks, the final biomass of each cage was obtained ( $n=4$ for each experimental group). Twenty fish per cage (80 fish per condition) were anesthetized and sacrificed in order to obtain body weight and length and the livers and mesenteric fat to calculate both HSI and MFI, respectively. Moreover, SGR and CF were calculated for each cage biomass ( $n=4$ for each experimental group). Samples of liver and epaxial white muscle of three fish per cage were obtained, frozen in liquid nitrogen and maintained at $-80^{\circ} \mathrm{C}$ until further analysis $(n=12$ for each experimental group or condition). FCR was also calculated.

\subsubsection{Gilthead Sea Bream Juveniles}

Two hundred and eighty juveniles (initial body weight $16.3 \pm 0.15 \mathrm{~g}$ ) obtained from the same hatchery were distributed into eight tanks (200 L) (35 fish/tank), as previously described [12]. The reared conditions were the same before indicated. Fish were fed ad libitum (near 5\% body weight/day) three times a day (7:30, 14:00 and 21:40) with a commercial diet (D-2 Optibream AE-1P, Skretting, Burgos, Spain). After three weeks of adaptation, four tanks were randomly selected for each experimental group; Control or rBGH. All fish were anesthetized, weighed and sized and intraperitoneally injected with a single dose (6 mg/g body weight) of $\mathrm{rBGH}$ or with the same volume of sesame oil for the controls, and recovered into their corresponding tank. At 9 weeks post-injection, body length and weight of all fish were recorded to calculate SGR and CF of each fish. FCR was also calculated. Three fish from each tank ( $n=12$ per condition) were anesthetized and sacrificed and then liver and mesenteric fat weighed in order to calculate HSI and MFI, respectively. Samples of liver, red and white muscle were obtained, immediately frozen in liquid nitrogen and stored at $-80^{\circ} \mathrm{C}$ until further analysis.

The experiments complied with the guidelines of the Council of the European Union (EU 2010/63) and the University of Barcelona (Spain) ethical standards for the use of laboratory animals (CEEA 208/14 and DAAM 7956).

\subsection{Proximal and Isotopic Composition $\left(\delta^{15} \mathrm{~N}\right.$ and $\left.\delta^{13} \mathrm{C}\right)$ of Tissues}

According to our previous studies [37], samples of liver, red and white muscle were ground in liquid $\mathrm{N}_{2}$ using a pestle and mortar to obtain a fine powder. Aliquots of each sample were taken for use in isotopic analyses and to assess the lipid, protein, glycogen and water content. The latter was determined gravimetrically after drying the samples at $95^{\circ} \mathrm{C}$ for $24 \mathrm{~h}$. Lipids were extracted as described by Bligh and Dyer [62]; lipid extracts were dried under a $\mathrm{N}_{2}$ atmosphere, and total lipids determined gravimetrically. Proteins were purified from defatted tissue samples via precipitation with $10 \%(v / v)$ trifluoroacetic acid. The extracts were dried using a vacuum system (Speed Vac Plus AR, Savant Speed Vac Systems, South San Francisco, CA, USA), and the protein content was calculated from the total N content obtained by elemental analysis (Elemental Analyser Flash 1112, ThermoFinnigan, Bremen, Germany), assuming $1 \mathrm{~g}$ of $\mathrm{N}$ for every $6.25 \mathrm{~g}$ of protein. Glycogen was extracted and purified following alkaline hydrolysis of tissues by boiling with $30 \% \mathrm{KOH}$ and an alcoholic precipitation, as described by Good et al. [63]. Glycogen content was then assessed using the anthrone colorimetric method described by Fraga [64].

Samples of diet and white muscle were lyophilized and grounded into a homogenous powder for isotopic analysis. Aliquots of the diet and their purified fractions (lipid and protein) and of white muscle, together with their purified tissue fractions (glycogen, lipid and protein), which ranged from 0.3 to $0.6 \mathrm{mg}$, were weighed in small tin capsules. Samples were analysed to determine the carbon and nitrogen isotope composition using a Mat Delta C Isotope Ratio mass spectrometer (Finnigan MAT, Bremen, Germany) coupled to a Flash 
1112 Elemental Analyzer. Isotope ratios $\left({ }^{15} \mathrm{~N} /{ }^{14} \mathrm{~N},{ }^{13} \mathrm{C} /{ }^{12} \mathrm{C}\right)$ determined by isotope ratio mass spectrometry are expressed in delta $(\delta)$ units (parts per thousand, \%o), as follows:

$$
\delta=[(\text { Rsa } / \text { Rst })-1] \times 1000
$$

where Rsa is the ${ }^{15} \mathrm{~N} /{ }^{14} \mathrm{~N}$ or ${ }^{13} \mathrm{C} /{ }^{12} \mathrm{C}$ ratio of samples and Rst is the ${ }^{15} \mathrm{~N} /{ }^{14} \mathrm{~N}$ or ${ }^{13} \mathrm{C} /{ }^{12} \mathrm{C}$ ratio of the international standards (Vienna Pee Dee Belemnite for $\mathrm{C}$ and air for $\mathrm{N}$ ). The same reference material analysed over the experimental period was measured with $\pm 0.2 \%$ precision. Nitrogen and carbon isotopic fractionation values $\left(\Delta \delta^{15} \mathrm{~N}\right.$ and $\left.\Delta \delta^{13} \mathrm{C}\right)$ were calculated as the difference between the $\delta$ value in the tissue and their corresponding $\delta$ value in the diet.

\subsection{Nucleic Acid Quantification and Enzyme Activity}

White muscle nucleic acid levels (RNA and DNA) were determined using the UVbased procedures for fish samples described by Buckley and Bulow [65]. RNA and DNA from muscle samples were hydrolysed to nucleotides, and their concentrations were calculated based on their absorbance at $260 \mathrm{~nm}$. Nucleic acid concentrations were expressed as $\mu \mathrm{g}$ of RNA or DNA per mg of wet tissue. An aliquot of supernatant was also used to determine protein content [66].

Metabolic enzyme activity was assayed from red and white muscle (CS and COX) or liver (CS, COX, LDH, ALAT, ASAT and HOAD) extracts obtained by homogenizing frozen tissue in detergent solution (1.24 mM TRITON X-100, $1 \mathrm{mM}$ EDTA and $1 \mathrm{mM}$ $\mathrm{NaHCO}$ ) and stabilizing solution (3.7 mM EDTA and $5 \mathrm{mM} 2-\beta$-mercaptoethanol), 1:1 $\mathrm{v} / \mathrm{v}$, as previously explained [49]. Homogenates were centrifuged at $700 \mathrm{~g}$ at $4{ }^{\circ} \mathrm{C}$ for $10 \mathrm{~min}$. The microtitration assays (final volume $200 \mu \mathrm{L}$ ) to obtain maximal enzyme activity were performed as follows: ASAT (aspartate aminotransferase, EC 2.6.1.1): $50 \mathrm{mM}$ Tris- $\mathrm{HCl}$ buffer (pH 7.4), $10 \mathrm{mM} \alpha$-ketoglutarate, $0.3 \mathrm{mM} \mathrm{NADH}, 25 \mathrm{mM}$ l-aspartate (substrate); ALAT (alanine aminotransferase, EC 2.6.1.2): $50 \mathrm{mM}$ Tris- $\mathrm{HCl}$ buffer ( $\mathrm{pH}$ 7.4), $10 \mathrm{mM}$ $\alpha$-ketoglutarate, $0.3 \mathrm{mM} \mathrm{NADH}, 25 \mathrm{mM}$ l-alanine (substrate); LDH (lactate dehydrogenase, EC 1.1.2.4): $50 \mathrm{mM}$ Tris- $\mathrm{HCl}$ buffer (pH 7.4), $0.16 \mathrm{mM} \mathrm{NADH}, 1 \mathrm{mM}$ pyruvate (substrate). HOAD (3-hydroxyacyl CoA dehydrogenase, E.C 1.1.1.35): $71.4 \mathrm{mM}$ imidazole buffer (pH 8.0), 2 mM NADH, 2 mM acetoacetyl-CoA (substrate). Citrate synthase (CS, EC 2.3.3.1) activity was determined from absorbance increases at $412 \mathrm{~nm}$ of DTNB reagent, using oxaloacetic acid as the substrate, following the method described by Srere [67]. Cytochromec-oxidase (COX, EC 1.9.3.1) activity was determined by adapting a commercial kit (CYTOCOX1, Sigma-Aldrich Inc., St. Louis, MO, USA). This colorimetric assay measures the reduction in ferrocytochrome $\mathrm{c}$ absorbance caused by oxidation of the latter by COX.

Redox enzyme activities (CAT, SOD, GR and GPX) were assayed from liver extracts obtained by homogenizing in 1:9 $(w / v)$ cold buffer (Tris-HCl $0.1 \mathrm{M}$, EDTA $0.1 \mathrm{mM}$, TRITON $\mathrm{X}-100, \mathrm{pH} 7.8$ ), following the previously published procedures [68]. Homogenates were centrifuged at $25,000 \mathrm{~g}$ at $4{ }^{\circ} \mathrm{C}$ for $30 \mathrm{~min}$. Superoxide dismutase (SOD, EC 1.15.1.1) was determined using method of McCord and Fridovich [69] and adapted for fish [70]: $50 \mathrm{mM}$ potassium phosphate buffer ( $\mathrm{pH}$ 7.8), $0.1 \mathrm{mM}$ EDTA, $1 \mathrm{mM}$ cytochrome $\mathrm{C}, 1 \mathrm{mM}$ Xanthine, $0.5 \mathrm{IU} / \mathrm{mL}$ xanthine oxidase and sodium hydrosulphite; Catalase (CAT, EC 1.11.1.6) was analysed according to Aebi [71]: $50 \mathrm{mM}$ potassium phosphate buffer, $\mathrm{pH}$ 7.0, $10.6 \mathrm{mM}$ $\mathrm{H}_{2} \mathrm{O}_{2}$. Glutathione peroxidase (GPX; EC 1.11.1.9) was assayed by measuring the oxidation of NADPH at $340 \mathrm{~nm}$ [72]: $50 \mathrm{mM}$ potassium phosphate buffer, $\mathrm{pH} 7.2,1 \mathrm{mM}$ EDTA, $2 \mathrm{mM}$ sodium azide, $0.5-1 \mathrm{U} / \mathrm{mL}$ glutathione reductase, $2 \mathrm{mM}$ reduced gluthatione, $0.1 \mathrm{mM}$ NADPH. Glutathione reductase (GR, EC 1.8.1.7) was measured by analysing NADPH oxidation at $340 \mathrm{~nm}$ [73]: $0.1 \mathrm{mM}$ potassium phosphate buffer, $\mathrm{pH} 7.5,1 \mathrm{mM}$ EDTA, $0.63 \mathrm{mM}$ NADPH and $3.25 \mathrm{mM}$ oxidized glutathione.

All enzymatic activity measurements were performed in 96-well microplates in duplicate at room temperature $\left(20^{\circ} \mathrm{C}\right)$ with a Tecan M200 spectrophotometer (Tecan Trading AG, Männedorf, Switzerland). All reagents, substrates, coenzymes and purified enzymes were purchased from Sigma-Aldrich (Tres Cantos, Spain) and Bio-Rad Laboratories, Inc. 
(Berkeley, CA, USA). All enzyme activities were expressed in milliunits (mUI) per mg of wet tissue, one unit being the amount of enzyme that converts $1 \mu \mathrm{mol}$ of substrate per min. Another aliquot of the supernatant was used to determine the protein content in accordance with the Bradford method [65].

\subsection{Western Blot}

Protein was extracted from $100 \mathrm{mg}$ of skeletal white muscle in $1 \mathrm{~mL}$ of RIPA buffer supplemented with phosphatase (PMSF and $\mathrm{NA}_{3} \mathrm{VO}_{4}$ ) and protease inhibitors (P8340, Sigma-Aldrich) using the Precellys ${ }^{\circledR}$ Evolution coupled to a Cryolys cooling system (Bertin Technologies, Montigny-le-Bretonneux, France). Soluble protein concentration was determined by the Bradford's method using BSA (Sigma-Aldrich, St. Louis, MO, USA) for the standard curve.

Twenty $\mu \mathrm{g}$ of the soluble protein fraction were prepared in a loading buffer (containing SDS and $\beta$-mercaptoethanol), heated at $95^{\circ} \mathrm{C}$ for $5 \mathrm{~min}$ and separated in polyacrylamide gel (12\% for CS and PGC1 $\alpha ; 15 \%$ for COX4). Following, the proteins were transferred overnight to Immobilon ${ }^{\circledR}$ PVDF-FL $0.2 \mu \mathrm{m}$ Transfer Membranes (Merck Millipore Ltd., Tullagreen, Cork, Ireland), previously activated in methanol. Total transferred protein was determined by $5 \mathrm{~min}$ incubation with Ponceau S (Sigma-Aldrich). The membranes were blocked in $5 \%$ skimmed powder milk solution in TBST buffer for $1 \mathrm{~h}$ at room temperature and then incubated overnight at $4{ }^{\circ} \mathrm{C}$ and in agitation with the corresponding diluted primary antibody. The primary antibodies used were purchased from ABCAM (Cambridge, UK) as follows: rabbit polyclonal anti-Cox IV antibody (ab16056) 1/1000, rabbit polyclonal anti-citrate synthase antibody (ab96600) $1 / 2000$, rabbit polyclonal anti-PGC1 $\alpha$ antibody (ab54481) 1/1000. The cross-reactivity of these antibodies with gilthead sea bream was confirmed by the molecular weight of the bands. Subsequently after washing with TBS$\mathrm{T}$, the membranes were incubated with a secondary antibody: mouse anti-rabbit IgGHRP (sc-2357) 1/15000. After incubation, membranes were washed with TBS-T, and the immunoreactive bands were developed by an enhanced chemiluminescence kit (Pierce ECL Western Blot Substrate, Thermo Scientific, Alcobendas, Spain). The densitometry of the total transferred protein and the immunoreactive bands was measured using the Quantity One tm software (Bio-Rad), and the relative densitometry was determined for each well.

\subsection{Proteome Analysis}

\subsubsection{Protein Extraction and 2-Dimesional Electrophoresis Separation}

Approximately $0.3 \mathrm{~g}$ of frozen muscle tissue was mechanically powdered in a mortar cooled with liquid nitrogen and homogenized in $3 \mathrm{~mL}$ ice-cold phosphate buffer ( $50 \mathrm{mM}$, $\mathrm{pH}$ 7.0) containing Protease Inhibitor Cocktail (Sigma-Aldrich, St. Louis, MO, USA). An aliquot of $0.3 \mathrm{~mL}$ of each sample was stored for bulk protein determination. Homogenates were centrifuged at $15,000 \mathrm{~g}$ for $45 \mathrm{~min}$ at $4{ }^{\circ} \mathrm{C}$, and supernatants (soluble fraction) were collected. This soluble fraction consists mainly of sarcoplasmic proteins that are easily solubilized at low ionic strength. The protein content of supernatants was determined using the Bio-Rad Protein Assay (Bio-Rad Laboratories), and samples were aliquoted and stored at $-80{ }^{\circ} \mathrm{C}$ until required. Further protein purification was performed by precipitating the samples in 4 volumes of ice-cold acetone.

According to the previous protocol [36], $300 \mu \mathrm{g}$ of purified protein was dissolved into $450 \mu \mathrm{L}$ of rehydration solution containing $7 \mathrm{M}$ urea, $2 \mathrm{M}$ thiourea, $2 \% w / v$ CHAPS, and $0.5 \%$ v $v$ IPG buffer pH 3-10 NL (Amersham Biosciences Europe, now GE Healthcare, Madrid, Spain), $80 \mathrm{mM}$ DTT and $0.002 \%$ of bromophenol blue. The solution was then loaded onto 24-cm, $\mathrm{pH} 3-10 \mathrm{NL}$ IPG strips. Isoelectric focusing was performed using an IPGphor instrument (Amersham Biosciences), following the manufacturer's instructions (active rehydration at $50 \mathrm{~V}$ for $12 \mathrm{~h}$ followed by a linear gradient from 500 to $8000 \mathrm{~V}$ until $48,000 \mathrm{~V} / \mathrm{h}$ ) (see more details about gels in Supplementary materials (Figure S1)). The resolved proteins were fixed for $1 \mathrm{~h}$ in $40 \% v / v$ methanol containing $10 \% v / v$ acetic acid and stained overnight using colloidal Coomassie Blue G-250. 


\subsubsection{Gel Image Analysis}

Coomassie blue gels were scanned in a calibrated Image Scanner III densitometer (GE Healthcare, Barcelona, Spain) and digital images captured at a resolution of $300 \mathrm{dpi}$ in grey scale mode by Labscan 6.0 software (GE Healthcare, Barcelona, Spain) and saved as uncompressed TIFF files. Gels from six independent biological replicates were analysed using the software package Image Master 2D version 6.01 (GE Healthcare, Barcelona, Spain). Protein spots that varied in abundance between Control and rBGH samples were analysed for significance by unpaired sample $t$-test (SPSS v.16; Chicago, IL, USA). The Shapiro-Wilk test was previously used to ensure the normal distribution of data, and the equality of variances was determined by statistical Levene's test. The candidate spots selected for MS analysis presented $\geq 2$-fold change in normalized volume and proteins were manually in-gel digested with trypsin (Sequencing grade modified, Promega) following the procedure shown in [36]. Tryptic peptides were extracted from the gel matrix with $10 \%$ formic acid and acetonitrile; the extracts were pooled and dried in a vacuum centrifuge.

\subsubsection{LC-MS/MS Analysis and Database Search}

The dried-down peptide mixtures were analysed in a nanoAcquity liquid chromatographer (Waters, Mildorf, MA, USA)) coupled to an LTQ-Orbitrap Velos (Thermo Scientific, Bremen, Germany) mass spectrometer. The tryptic digests were resuspended in $1 \%$ FA solution, and an aliquot was injected for chromatographic separation (more details in Supplementary materials). Generated raw data files were collected with Thermo Xcalibur (v.2.2) and used to search against the public database Uniprot Actinopterygii (v.23/3/17). A database containing common laboratory contaminant proteins was added to this database. The software used was Thermo Proteome Discoverer (v.1.4.1.14) with Sequest HT as the search engine. The search parameters applied are shown in Supplementary materials (Supplementary text). All possible protein identifications from analyses that met the above criteria were reported for each gel spot. However, the protein identification with the highest score, discarding contaminants, was selected in the case of redundant protein identifications. The Batch-Genes tool produced by GOEAST (http:/ / omicslab.genetics.ac.cn/GOEAST/2019, access on 11 November 2021) performed enrichment analyses of GO annotation terms for biological processes. The proteomics work was done at the Proteomics Platform of Barcelona Science Park, University of Barcelona, a member of ProteoRed-ISCIII network.

\subsection{Statistical Analysis}

Data are presented as mean \pm standard error of the mean (SEM) and were analysed using the software IBM SPSS Statistics V.22. A two-way ANOVA was used with condition (rBGH or control groups) as a fixed factor and tank as a random factor, after checking for normal distribution of data and equality of variances using the Shapiro-Wilk and Levene's test, respectively. As there were not significant effects of factor tank for any of the variables analysed, a Student's $t$-test comparison was used, being the sample sizes used to compare between the two groups $n=4$ (tanks per condition) for growth parameters and FCR and $n=12$ per condition (three fish per 4 tanks) for all the variables, except for HSI and MFI $(n=80$ per condition). Differences were considered significant at $p<0.05$.

Supplementary Materials: The following are available online at https://www.mdpi.com/article/ $10.3390 /$ ijms222313107/s1.

Author Contributions: Conceptualization, J.B., J.F.-B. and J.G.; methodology, M.P.-A., E.J.V., S.A. and E.C.; software, M.P.-A. and S.A.; validation, J.B., J.F.-B., E.C. and J.G.; formal analysis, M.P.-A., S.A., E.J.V., J.F.-B. and J.B.; investigation, J.B., M.P.-A., E.J.V., J.F.-B., E.C. and J.G.; resources, J.G.; data curation, J.B., J.F.-B., E.J.V., M.P.-A., S.A., E.C. and J.G.; writing-original draft preparation, J.B. and J.G.; writingreview and editing, J.B., E.J.V., J.F.-B., E.C. and J.G.; visualization, J.B., J.F.-B., E.J.V., M.P.-A., S.A., E.C. and J.G.; supervision, J.B. and J.G.; project administration, J.B., J.F.-B. and J.G.; funding acquisition, J.G. and J.B. All authors have read and agreed to the published version of the manuscript. 
Funding: This research was funded from the Spanish "Ministerio de Ciencia, Innovación y Universidades" (MICIUN) AGL2015-70679-R and RTI2018-100757-B-I00 to J.G. and J.B. and the "Generalitat de Catalunya" (2017SGR-1574). M.P. and E.J.V. were supported by predoctoral fellowships from the MICIUN BES-2016-078697 and BES-2013-062949, respectively.

Institutional Review Board Statement: The experiments complied with the guidelines of the Council of the European Union (EU 2010/63) and the University of Barcelona (Spain) ethical standards for the use of laboratory animals (CEEA 208/14 and DAAM 7956).

Informed Consent Statement: Not applicable.

Data Availability Statement: The datasets used and/or analyzed during the current study are available from the corresponding author upon reasonable request.

Acknowledgments: The authors would like to thank the personnel from the animal facilities of the Faculty of Biology for the maintenance of the fish.

Conflicts of Interest: The authors declare no conflict of interest.

\section{References}

1. Árnason, T.; Gunnarsson, A.; Steinarsson, A.; Danñielsdóttir, A.K.; Björnsson, B.T. Impact of temperature and growth hormone on growth physiology of junenile Atlantic wolffish (Anarhichas lupus). Aquaculture 2019, 504, 404-413. [CrossRef]

2. Devlin, R.H.; Biagi, C.A.; Yesaki, T.Y.; Smailus, D.E.; Byatt, J.C. Growth of domesticated transgenic fish. Nature 2001, 409, 781-782. [CrossRef]

3. Duan, C. The insulin-like growth factor system and its biological actions in fish. Integr. Comp. Biol. 1997, 37, 491-503. [CrossRef]

4. McLean, E.; Devlin, R.H. Seaweeds and invertebrates. In Recent Advances in Marine Biotechnology, Aquaculture: Part A; Fingerman, M., Nagabhushanam, R., Eds.; Science Publishers, Inc.: Endfield, CT, USA, 2000; Volume 4.

5. Leedom, T.A.; Uchida, K.; Yada, T.; Richman, N.H.; Byatt, J.C.; Collier, R.J.; Hirano, T.; Grau, E.G. Recombinant bovine growth hormone treatment of tilapia: Growth response, metabolic clearance, receptor binding and immunoglobulin production. Aquaculture 2002, 207, 359-380. [CrossRef]

6. Peterson, B.C.; Small, B.C.; Bosworth, B.G. Effects of bovine growth hormone (Posilac ${ }^{\circledR}$ ) on growth performance, body composition, and IGFBPs in two strains of channel catfish. Aquaculture 2004, 232, 651-663. [CrossRef]

7. Bower, N.I.; Johnston, I.A. Transcriptional regulation of the IGF signaling pathway by amino acids and insulin-like growth factors during myogenesis in Atlantic salmon. PLoS ONE 2010, 5, e11100. [CrossRef] [PubMed]

8. Raven, P.A.; Sakhrani, D.; Beckman, B.; Neregård, L.; Sundström, L.F.; Björnsson, B.T.; Devlin, R.H. Growth and endocrine effects of recombinant bovine growth hormone treatment in non-transgenic and growth hormone transgenic coho salmon. Gen. Comp. Endocrinol. 2012, 177, 143-152. [CrossRef] [PubMed]

9. Fuentes, E.N.; Valdés, J.A.; Molina, A.; Björnsson, B.T. Regulation of skeletal muscle growth in fish by the growth hormoneinsulin-like growth factor system. Gen. Comp. Endocrinol. 2013, 192, 136-148. [CrossRef]

10. Vélez, E.J.; Lutfi, E.; Azizi, S.; Perelló, M.; Salmerón, C.; Riera-Codina, M.; Ibarz, A.; Fernández-Borràs, J.; Blasco, J.; Capilla, E.; et al. Understanding fish muscle growth regulation to optimize aquaculture production. Aquaculture 2017, 467, 28-40. [CrossRef]

11. Vélez, E.J.; Perelló, M.; Azizi, S.; Moya, A.; Lutfi, E.; Pérez-Sánchez, J.; Calduch-Giner, J.A.; Navarro, I.; Blasco, J.; FernándezBorràs, J.; et al. Recombinant bovine growth hormone (rBGH) enhances somatic growth by regulating the GH-IGF axis in fingerlings of gilthead sea bream (Sparus aurata). Gen. Comp. Endocrinol. 2018, 257, 192-202. [CrossRef] [PubMed]

12. Vélez, E.J.; Perelló-Amorós, M.; Lutfi, E.; Azizi, S.; Capilla, E.; Navarro, I.; Pérez-Sánchez, J.; Calduch-Giner, J.A.; Blasco, J.; Fernández-Borràs, J.; et al. A long-term growth hormone treatment stimulates growth and lipolysis in gilthead sea bream juveniles. Comp. Biochem. Physiol. Part A Mol. Integr. Physiol. 2019, 232, 67-78. [CrossRef]

13. Le Roith, D.; Bondy, C.; Yakar, S.; Liu, J.L.; Butler, A. The somatomedin hypothesis. Endocr. Rev. 2001, 22, 53-74. [CrossRef] [PubMed]

14. Reindl, K.M.; Sheridan, M.A. Peripheral regulation of the growth hormone-insulin-like growth factor system in fish and other vertebrates. Comp. Biochem. Physiol. A. Mol. Integr. Physiol. 2012, 163, 231-245. [CrossRef]

15. Vélez, E.J.; Unniappan, S.A. Comparative update on the neuroendocrine regulation of growth hormone in vertebrates. Front. Endocrinol. 2021, 11, 614981. [CrossRef]

16. Sweeney, G. Leptin signalling. Cell Signal. 2002, 14, 655-663. [CrossRef]

17. Reinecke, M.; Björnsson, B.T.; Dickhoff, W.W.; McCormick, S.D.; Navarro, I.; Power, D.M.; Gutierrez, J. Growth hormone and insulin-like growth factors in fish: Where we are and where to go. Gen. Comp. Endocrinol. 2005, 142, 20-24. [CrossRef]

18. Møller, N.; Jørgensen, J.O.L. Effects of growth hormone on glucose, lipid, and protein metabolism in human subjects. Endocr. Rev. 2009, 30, 152-177. [CrossRef]

19. Mommsen, T.P. Growth and metabolism. In The Physiology of Fishes; Evans, D.H., Ed.; CRC Press: Boca Raton, FL, USA, $1998 ;$ pp. 65-97.

20. Sangiao-Alvarellos, S.; Míguez, J.M.; Soengas, J.L. Actions of growth hormone on carbohydrate metabolism and osmoregulation of rainbow trout (Oncorhynchus mykiss). Gen. Comp. Endocrinol. 2005, 141, 214-225. [CrossRef] 
21. O'Connor, P.K.; Reich, B.; Sheridan, M.A. Growth hormone stimulates hepatic lipid mobilization in rainbow trout, Oncorhynchus mykiss. J. Comp. Physiol. 1993, 163B, 427-431. [CrossRef]

22. Leena, S.; Oommen, O.V. Growth hormone and prolactin action in a teleost Anabas testudineus (Bloch): Effect of the time of administration. Biol. Rhythm Res. 2001, 32, 501-510. [CrossRef]

23. Leung, T.C.; Ng, T.B.; Woo, N.Y.S. Metabolic effects of bovine growth hormone in the tilapia Oreochromis mossambicus. Comp. Biochem. Physiol. A 1991, 99, 633-636. [CrossRef]

24. Matty, A.J. Effects of mammalian growth hormone on Cottus scorpius blood. Nature 1962, 195, 506-507. [CrossRef]

25. McKeown, B.A.; Leatherland, J.F.; John, T.M. The effect of growth hormone and prolactin on the mobilization of free fatty acids and glucose in the kokanee salmon (Oncorhynchus nerka). Comp. Biochem. Physiol. 1975, 50B, 425-430. [CrossRef]

26. Sweeting, R.M.; Wagner, G.F.; McKeown, B.A. Changes in plasma glucose, amino acid nitrogen and growth hormone during smoltification and seawater adaptation in coho salmon, Oncorhynchus kisutch. Aquaculture 1985, 45, 185-197. [CrossRef]

27. Aas-Hansen, Ø.; Jørgensen, E.H.; Vijayan, M.M. Fasting modulates metabolic responses to cortisol, GH and IGF-I in Arctic charr hepatocytes. J. Fish Biol. 2005, 67, 1631-1645. [CrossRef]

28. Foster, A.R.; Houlihan, D.F.; Gray, C.; Medale, F.; Fauconneau, B.; Kaushik, S.; le Bail, P.Y. The effects of ovine growth hormone on protein turnover in rainbow trout. Gen. Comp. Endocrinol. 1991, 82, 111-120. [CrossRef]

29. Fauconneau, B.; Mady, M.; Le Bail, P.Y. Effect of growth hormone on muscle protein synthesis in rainbow trout Oncorhynchus mykiss and Atlantic salmon Salmo salar. Fish Physiol. Biochem. 1996, 15, 49-56. [CrossRef]

30. Herbert, N.A.; Armstrong, J.D.; Björnsson, B.T. Evidence that growth hormone-induced elevation in routine metabolism of juvenile Atlantic salmon is a result of increased spontaneous activity. J. Fish Biol. 2001, 59, 754-757. [CrossRef]

31. Causey, D.R.; Kim, J.H.; Stead, D.A.; Martin, S.A.M.; Devlin, R.H.; Macqueen, D.J. Proteomic comparison of selective breeding and growth hormone transgenesis in fish: Unique pathways to enhanced growth. J. Proteom. 2019, 192, 114-124. [CrossRef] [PubMed]

32. Martínez Del Rio, C.; Wolf, N.; Carleton, S.A.; Gannes, L.Z. Isotopic ecology ten years after a call for more laboratory experiments. Biol. Rev. 2009, 84, 91-111. [CrossRef]

33. Gannes, L.Z.; Marti, C. Natural abundance variations in stable isotopes and their potential uses in animal physiological ecology. Comp. Biochem.Physiol. Part A. 1998, 119, 725-737. [CrossRef]

34. Martin-Pérez, M.; Fernández-Borràs, J.; Ibarz, A.; Felip, O.; Gutierrez, J.; Blasco, J. Stable isotope analysis combined with metabolic indices discriminates between gilthead sea bream (Sparus aurata) fingerlings produced in various hatcheries. J. Agric. Food Chem. 2011, 59, 10261-10270. [CrossRef]

35. Beltrán, M.; Fernández-Borrás, J.; Médale, F.; Pérez-Sánchez, J.; Kaushik, S.; Blasco, J. Natural abundance of 15N and 13C in fish tissues and the use of stable isotopes as dietary protein tracers in rainbow trout and gilthead sea bream. Aquac. Nutr. 2009, 15, 9-18. [CrossRef]

36. Martin-Pérez, M.; Fernández-Borràs, J.; Ibarz, A.; Millan-Cubillo, A.; Felip, O.; de Oliveira, E.; Blasco, J. New insights into fish swimming: A proteomic and isotopic approach in gilthead sea bream. J. Proteome Res. 2012, 11, 3533-3547. [CrossRef] [PubMed]

37. Martin-Pérez, M.; Fernández-Borràs, J.; Ibarz, A.; Felip, O.; Fontanillas, R.; Gutiérrez, J. Naturally occurring stable isotopes reflect changes in protein turnover and growth in gilthead sea bream (Sparus aurata) juveniles under different dietary protein levels. $J$. Agric. Food Chem. 2013, 61, 8924-8933. [CrossRef] [PubMed]

38. Biga, P.R.; Meyer, J. Growth hormone differentially regulates growth and growth-related gene expression in closely related fish species. Comp. Biochem. Physiol. A 2009, 154, 465-473. [CrossRef]

39. Fenn, C.M.; Small, B.C. Exogenous recombinant bovine growth hormone stimulates growth and hepatic IGF expression in shovelnose sturgeon Scaphirhynchus platorhynchus. Comp. Biochem. Physiol. A 2015, 180, 18-22. [CrossRef]

40. McLean, E.; Devlin, R.H.; Byatt, J.C.; Clarke, W.C.; Donaldson, E.M. Impact of a controlled release formulation of recombinant bovine growth hormone upon growth and seawater adaptation in coho (Oncorhynchus kisutch) and chinook (Oncorhynchus tshawytscha) and salmon. Aquaculture 1997, 156, 113-128. [CrossRef]

41. Garber, M.J.; DeYonge, K.G.; Byatt, J.C.; Lellis, W.A.; Honeyfield, D.C.; Bull, R.C.; Schelling, G.T.; Roeder, R.A. Dose-response effects of recombinant bovine somatotropin (Posilac) on growth performance and body composition of two-year-old rainbow trout (Oncorhynchus mykiss). J. Anim. Sci. 1995, 73, 3216-3222. [CrossRef]

42. Johnsson, J.I.; Björnsson, B.T. Growth hormone increases growth rate, appetite and dominance in juvenile rainbow trout, Oncorhynchus mykiss. Anim. Behav. 1994, 47, 177-186. [CrossRef]

43. Kling, P.; Jönsson, E.; Nilsen, T.O.; Einarsdottir, I.E.; Rønnestad, I.; Stefansson, S.O.; Björnsson, B.T. The role of growth hormone in growth, lipid homeostasis, energy utilization and partitioning in rainbow trout: Interactions with leptin, ghrelin and insulin-like growth factor I. Gen. Comp. Endocrinol. 2012, 175, 153-162. [CrossRef]

44. Fauconneau, B.; Andre, S.; Chmaitilly, J.; Bail, P.Y.; Krieg, F.; Kaushik, S.J. Control of skeletal muscle fibres and adipose cells size in the flesh of rainbow trout. J. Fish Biol. 1997, 50, 296-314. [CrossRef]

45. Leatherland, J.F.; Nuti, R.N. Effects of bovine growth hormone on plasma FFA concentrations and liver, muscle and carcass lipid content in rainbow trout, Salmo gairdneri Richardson. J. Fish Biol. 1981, 19, 487-498. [CrossRef]

46. Albalat, A.; Gómez-Requeni, P.; Rojas, P.; Médale, F.; Kaushik, S.; Vianen, G.J.; van den Thillart, G.; Gutiérrez, J.; Pérez-Sánchez, J.; Navarro, I. Nutritional and hormonal control of lipolysis in isolated gilthead seabream (Sparus aurata) adipocytes. Am. J. Physiol. Reg. Integr. Comp. Physiol. 2005, 289, R259-R265. [CrossRef] 
47. Bergan, H.E.; Kittilson, J.D.; Sheridan, M.A. PKC and ERK mediate Gh stimulated lipolysis. J. Mol. Endocrinol. 2013, 51, $213-224$. [CrossRef] [PubMed]

48. Bergan, H.E.; Kittilson, J.D.; Sheridan, M.A. Nutritional state modulates growth hormone-stimulated lipolysis. Gen. Comp. Endocrinol. 2015, 217, 1-9. [CrossRef] [PubMed]

49. Blasco, J.; Moya, A.; Millán-Cubillo, A.; Vélez, E.J.; Capilla, E.; Pérez-Sánchez, J.; Gutiérrez, J.; Fernández-Borràs, J. Growthpromoting effects of sustained swimming in fingerlings of gilthead sea bream (Sparus aurata L.). J. Comp. Physiol. B. 2015, 185, 859-868. [CrossRef] [PubMed]

50. Rasmussen, R.S.; Rønsholdt, B.; Ostenfeld, T.H.; McLean, E.; Byatt, J.C. Growth, feed utilisation, carcass composition and sensory characteristics of rainbow trout treated with recombinant bovine placental lactogen and growth hormone. Aquaculture 2001, 195, 367-384. [CrossRef]

51. McKenzie, D.J.; Martínez, R.; Morales, A.; Acosta, J.; Morales, R.; Taylor, E.W.; Steffensen, J.F.; Estrada, M.P. Effects of growth hormone transgenesis on metabolic rate, exercise performance and hypoxia tolerance in tilapia hybrids. J. Fish. Biol. 2003, 63, 398-409. [CrossRef]

52. Short, K.R.; Møller, N.; Bigelow, M.L.; Coenen-Schimke, J.; Nair, K.S. Enhancement of muscle mitochondrial function by growth hormone. J. Clin. Endocrinol. Metab. 2008, 93, 597-604. [CrossRef]

53. Lange, K.H.; Isaksson, F.; Juul, A.; Rasmussen, M.H.; Bülow, J.; Kjaer, M. Growth hormone enhances effects of endurance training on oxidative muscle metabolism in elderly women. Am. J. Physiol. Endocrinol. Metab. 2000, 279, E989-E996. [CrossRef]

54. Leggatt, R.A.; Brauner, C.J.; Iwama, G.K.; Devlin, R.H. The glutathione antioxidant system is enhanced in growth hormone transgenic coho salmon (Oncorhynchus kisutch). J. Comp. Physiol. B 2007, 177, 413-422. [CrossRef]

55. Tolomeo, A.M.; Carraro, A.; · Bakiu, R.; Toppo, S.; Garofalo, F.; Pellegrino, D.; Gerdol, M.; Ferro, D.; Place, S.P.; Santovito, G. Molecular characterization of novel mitochondrial peroxiredoxins from the Antarctic emerald rockcod and their gene expression in response to environmental warming. Comp. Biochem. Physiol. C 2019, 225, 108580.

56. Scarpulla, R.C. Metabolic control of mitochondrial biogenesis through the PGC-1 family regulatory network. Biochim. Biophys. Acta Mol. Cell Res. 2011, 1813, 1269-1278. [CrossRef]

57. Wenz, T. Regulation of mitochondrial biogenesis and PGC-1 $\alpha$ under cellular stress. Mitochondrion 2013, 13, 134-142. [CrossRef] [PubMed]

58. Mueller, I.A.; Grim, J.M.; Beers, J.M.; Crockett, E.L.; O’Brien, K.M. Interrelationship between mitochondrial function and susceptibility to oxidative stress in red- and white-blooded Antarctic notothenioid fishes. J. Exp. Biol. 2011, $214,3732-3741$. [CrossRef] [PubMed]

59. O'Brien, K.M. Mitochondrial biogenesis in cold-bodied fishes. J. Exp. Biol. 2011, 214, 275-285. [CrossRef] [PubMed]

60. Bermejo-Nogales, A.; Nederlof, M.; Benedito-Palos, L.; Ballester-Lozano, G.F.; Folkedal, O.; Olsen, R.E.; Sitjà-Bobadilla, A.; Pérez-Sánchez, J. Metabolic and transcriptional responses of gilthead sea bream (Sparus aurata L.) to environmental stress: New insights in fish mitochondrial phenotyping. Gen. Comp. Endocrinol. 2014, 205, 305-315. [CrossRef]

61. Panserat, S.; Kamalam, B.S.; Fournier, J.; Plagnes-Juan, E.; Woodward, K.; Devlin, R.H. Glucose metabolic gene expression in growth hormone transgenic coho salmon. Comp. Biochem. Physiol. 2014, 170, 38-45. [CrossRef]

62. Bligh, E.G.; Dyer, W.J. A rapid method of total lipid extraction and purification. Can. J. Biochem. Physiol. 1959, 37, 911-917. [CrossRef]

63. Good, C.A.; Kramer, H.; Somogyi, M. The determination of glycogen. J. Biol. Chem. 1933, 100, 485-491. [CrossRef]

64. Fraga, F. Determinación de glucógeno en moluscos con el reactivo de antrona. Inv. Pesq. 1956, 3, 69-74.

65. Buckley, L.J.; Bulow, F.J. Techniques for the Estimation of RNA, DNA and Protein in Fish; Iowa State University Press: Ames, IA, USA, 1987; p. 357.

66. Bradford, M.M. A rapid and sensitive method for the quantitation of microgram quantities of protein utilizing the principle of protein-dye binding. Anal. Biochem. 1976, 72, 248-254. [CrossRef]

67. Srere, P.A. Citrate synthase: EC 4.1.3.7. Citrate oxaloacetate-lyase (CoA-acetylating). In Methods in Enzymology; Lowenstein, J.M., Ed.; Academic Press: New York, NY, USA, 1969; Volume 13, pp. 3-11.

68. Sánchez-Nuño, S.; Sanahuja, I.; Ferández-Alacid, L.; Ordóñez-Grande, B.; Fontanillas, R.; Fernández-Borràs, J.; Blasco, J.; Carbonell, T.; Ibarz, A. Redox challenge in a cultured temperate marine species during low temperature and temperature recovery. Front. Physiol. 2018, 9, 923. [CrossRef] [PubMed]

69. McCord, J.M.; Fridovich, I. The utility of superoxide dismutase in studying free radical reactions. J. Biol. Chem. 1969, 244, 6056-6063. [CrossRef]

70. Furné, M.; García-Gallego, M.; Hidalgo, M.C.; Morales, A.E.; Domezain, A.; Domezain, J.; Sanz, A. Oxidative stress parameters during starvation and refeeding periods in Adriatic sturgeon (Acipenser naccarii) and rainbow trout (Oncorhynchus mykiss). Aquac. Nutr. 2009, 15, 587-595. [CrossRef]

71. Aebi, H. Catalase in vitro. Meth. Enzymol. 1984, 105, 121-126.

72. Bell, J.G.; Cowey, C.B.; Adron, J.W.; Shanks, A.M. Some effects of vitamin E and selenium deprivation on tissue enzyme levels and indices of tissue peroxidation in rainbow trout (Salmo gairdneri). Br. J. Nutr. 1985, 53, 149-157. [CrossRef]

73. Carlberg, I.; Mannervik, B. Glutathione reductase. Methods Enzymol. 1985, 113, 484-490. [PubMed] 